NATIONAL LABORATORY

MANAGED BY UT-BATTELLE

FOR THE DEPARTMENT OF ENERGY

\title{
ESA Protection for the American Eel: Implications for U.S. Hydropower
}

October 2013

Prepared by

\author{
H. I. Jager \\ B. Elrod, \\ N. Samu \\ R. A. McManamay, and \\ B. T. Smith
}

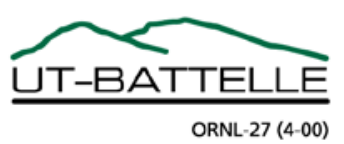




\section{DOCUMENT AVAILABILITY}

Reports produced after January 1, 1996, are generally available free via US Department of Energy (DOE) SciTech Connect.

Website http://www.osti.gov/scitech/

Reports produced before January 1, 1996, may be purchased by members of the public from the following source:

National Technical Information Service

5285 Port Royal Road

Springfield, VA 22161

Telephone 703-605-6000 (1-800-553-6847)

TDD 703-487-4639

Fax 703-605-6900

E-mailinfo@ntis.gov

Website http://www.ntis.gov/support/ordernowabout.htm

Reports are available to DOE employees, DOE contractors, Energy Technology Data Exchange representatives, and International Nuclear Information System representatives from the following source:

Office of Scientific and Technical Information

PO Box 62

Oak Ridge, TN 37831

Telephone 865-576-8401

Fax 865-576-5728

E-mail reports@osti.gov

Website http://www.osti.gov/contact.html

This report was prepared as an account of work sponsored by an agency of the United States Government. Neither the United States Government nor any agency thereof, nor any of their employees, makes any warranty, express or implied, or assumes any legal liability or responsibility for the accuracy, completeness, or usefulness of any information, apparatus, product, or process disclosed, or represents that its use would not infringe privately owned rights. Reference herein to any specific commercial product, process, or service by trade name, trademark, manufacturer, or otherwise, does not necessarily constitute or imply its endorsement, recommendation, or favoring by the United States Government or any agency thereof. The views and opinions of authors expressed herein do not necessarily state or reflect those of the United States Government or any agency thereof. 


\title{
ESA PROTECTION FOR THE AMERICAN EEL: IMPLICATIONS FOR U.S. HYDROPOWER
}

\author{
H. I. Jager \\ B. Elrod \\ N. Samu \\ R. A. McManamay \\ B. T. Smith
}

Date Published: October 2013

Prepared by

OAK RIDGE NATIONAL LABORATORY

Oak Ridge, Tennessee 37831-6283

managed by

UT-BATTELLE, LLC

for the

U.S. DEPARTMENT OF ENERGY

under contract DE-AC05-00OR22725 


\section{CONTENTS}

\section{Page}

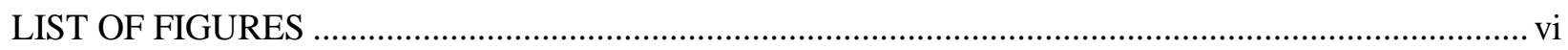

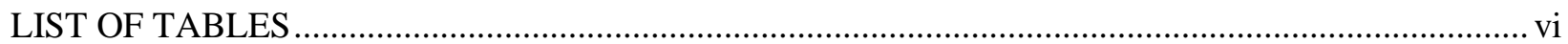

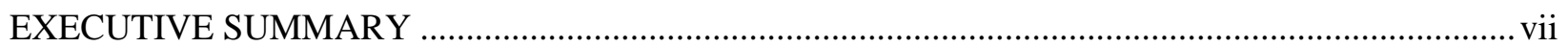

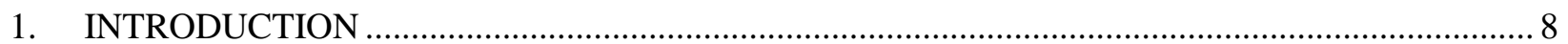

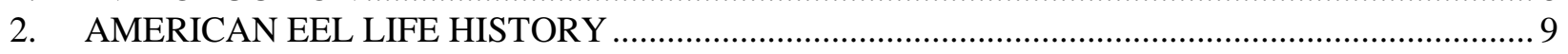

3. RISK ASSESSMENT: AMERICAN EEL LISTING AND FUTURE HYDROPOWER

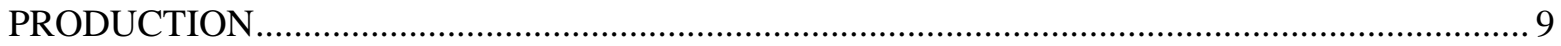

3.1 HOW DOES AMERICAN EEL PRESENCE IMPACT HYDROPOWER? ........................... 10

3.2 HOW DOES HYDROPOWER AFFECT AMERICAN EEL DISTRIBUTION? ................... 13

3.2.1 Can eels thrive without access to freshwater habitat?.............................................. 14

3.2.2 Can eels thrive in impounded freshwater habitat? ..................................................... 14

3.3 SPATIAL DATA USED TO ASSESS EEL-HYDROPOWER INTERACTION.................... 15

3.5 GOING UP—DAMS BLOCK ACCESS TO UPSTREAM FRESHWATER HABITAT ........ 16

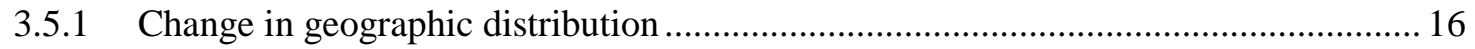

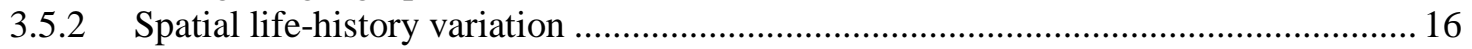

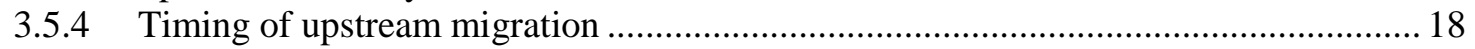

3.5.5 Effects of barriers on abundances and size distributions .......................................... 18

3.7 GOING DOWN-IMPINGEMENT, ENTRAINMENT, AND SPILL ................................ 19

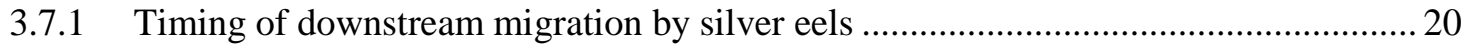

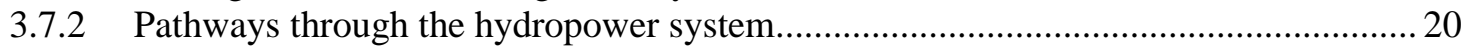

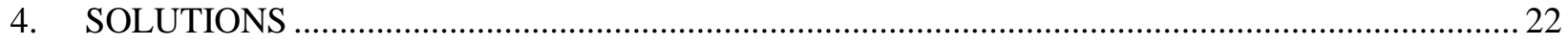

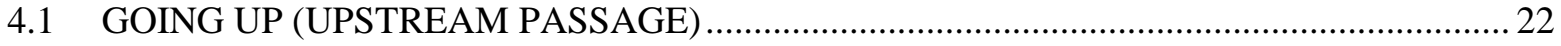

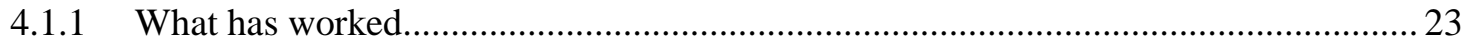

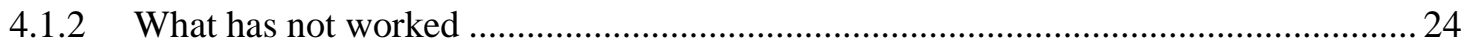

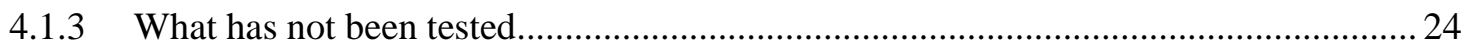

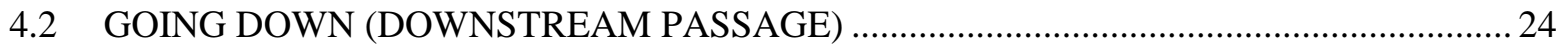

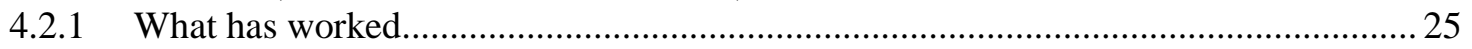

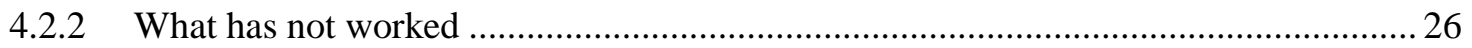

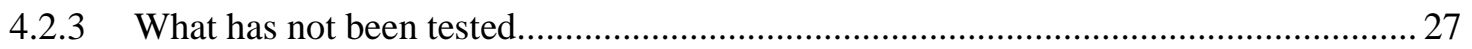

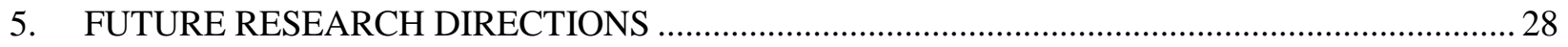

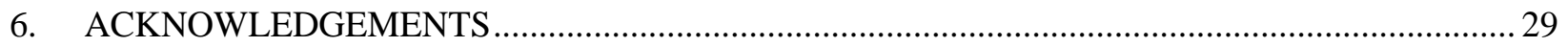

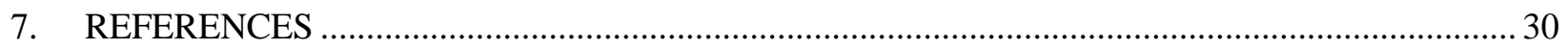

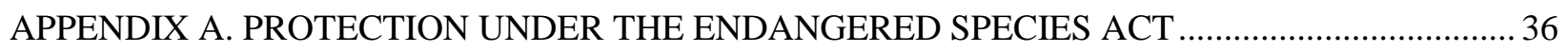




\section{LIST OF FIGURES}

Figures

Fig. 1. Life cycle of the American eel, Anguilla rostrata ...................................................................... 9

Fig. 2. Hydropower generation capacity at potential risk due to mitigation for the American eel.............. 10

Fig. 3. ESA listing the American eel could impact 32,719 MW of nameplate capacity at 939 US

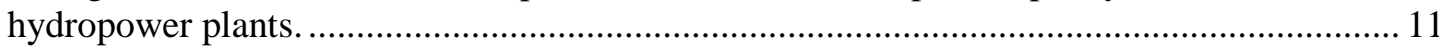

Fig. 4. ESA listing the American eel could impact 20,901 MW of nameplate capacity at 795

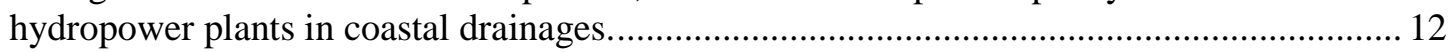

Fig. 5. Loss of freshwater habitat for the American eel................................................................... 17

Fig. 6. Decision process for survival of adult eels migrating downstream from freshwater to ocean. ....... 19

Fig. 7. Cross-section of the eel ladder on Chambly Dam (Verdon 2003)................................................. 23

\section{LIST OF TABLES}

\section{Tables}

Table 1. Estimates of eel densities and biomass for studies of Atlantic coastal rivers and estuaries

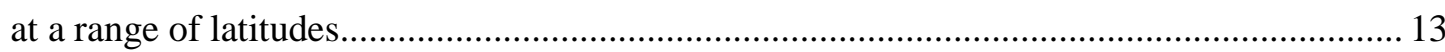

Table A1. Factors used to make a listing determination under the Endangered Species Act ..................... 37 


\section{EXECUTIVE SUMMARY}

The American eel (Anguilla rostrata) has been proposed for special protection in the United States under the Endangered Species Act (ESA). This conservation action could impact a significant number of hydropower plants. A spatial analysis of data from Oak Ridge National Laboratory's HydroGIS estimated that 32,719 MW of nameplate capacity is at risk at existing hydropower projects in the eastern United States. Most of these plants, with a combined capacity of 20,827 MW, are located in coastal river basins, and many of these occur in New England and Mid-Atlantic states.

For eels, upstream passage is both effective and relatively inexpensive to provide. However, ensuring safe downstream passage presents significant challenges. Combinations of technologies for guiding and/or collecting large, maturing eels during their downstream migration through the hydro-system are still in the early stages of development. Several promising future directions emerged from our review. These included design of eel-friendly turbines, intake screens, and bypasses and strategic approaches to bypass multiple hydropower projects by trapping eels upstream and transporting them around dams.

In this report, we review the state of the science in eel passage, including both upstream and downstream passage, where considerations include turbine impacts, and eel biology. We highlight promising avenues to guide future research and development efforts toward effective solutions that minimize impacts to hydropower production. From a broader geographic perspective, we recommend evaluating where the best opportunities for eel recovery exist. Unlike other fish species that migrate between freshwater and the ocean, juvenile eels do not necessarily return to one of the rivers occupied by their parents. This implies that the species will likely be managed as a single genetic stock, and efforts to avoid listing under ESA by preventing decline will be most effective if they are coordinated. By understanding the species' biology, it should be possible to focus eel conservation efforts in river systems with reduced impact to US hydropower production.

For further information or submission of comments, please contact:

Principal Investigator: Henriette (Yetta) Jager

Oak Ridge National Laboratory

P.O. Box 2008, MS 6036

Oak Ridge, TN 37831

Phone: (865) 574-8143

E-mail: jagerhi@.ornl.gov

Or,

Program Manager: Brennan T. Smith

Water Power Technologies

Oak Ridge National Laboratory

P.O. Box 2008, MS 6036

Oak Ridge, TN 37831

Phone: (865) 241-5160

E-mail:smithbt@.ornl.gov 


\section{INTRODUCTION}

The American eel (Anguilla rostrata) is being considered for listing as threatened under the Endangered Species Act (ESA). A listing determination for a species under section 4(a) of the Act (16 U.S.C. 1531 et seq.), will be made based on the factors in Appendix Table 1 (US Fish and Wildlife Service 2011). Listing could have a significant impact on the hydropower industry. All rivers and streams in the eastern United States constitute historical habitat for eels, especially projects in rivers along the Atlantic coast. Juvenile eels return from the spawning grounds in the Sargasso Sea to rear in rivers that drain to the Atlantic coast, as well as to Apalachicola Bay and the Gulf of Mexico. If listing is determined to be warranted, then designation of critical habitat will be proposed, focusing on "physical or biological features essential to the conservation of the species, within the geographical range currently occupied by the species and where these features are currently found” (US Fish and Wildlife Service 2011). In addition, the impetus to require both upstream and downstream passage mitigation will increase.

In this report, we summarize the state of the science as it pertains to conservation planning for this species. This summary includes

- A geospatial assessment of the overlap between historical American eel habitat and existing hydropower plants by affected nameplate capacity.

- A review of potential impacts to hydropower projects and generation capacity

- A review of issues related to eel habitat and passing eels, including proposed solutions, what has been shown to work, and what has not worked well

- Specific recommendations and proposed future research directions

- Key elements of the reviews and listing decisions under ESA relevant to industry 


\section{AMERICAN EEL LIFE HISTORY}

All American eels breed in the southwestern Sargasso Sea off the coast of North America (Fig. 1) (Kleckner et al. 1983). Spawning occurs in winter on either side of the Subtropical Convergence Zone between thermal density fronts (McCleave 1993). This species constitutes one well-mixed breeding population with no genetic sub-structure (Cote et al. 2013, Pujolar 2013). After hatching (between FebMar), larval eels (leptocephali) spawned in winter are carried by the Gulf Stream. This larval stage lasts $1.5 \mathrm{y}$. In spring or summer of the following year, they metamorphose into transparent 'glass' eels as they leave the Gulf Stream and approach the continental shelf. At this point, they begin active migration. Most glass eels migrate to the North American Atlantic coast (orange arrows, Fig. 1), but a small percentage traverse the Straits of Florida and enter the Gulf of Mexico and river systems that drain to the Gulf. Once in the estuary, glass eels (McCleave and Kleckner 1982), elvers, and yellow eels use tidal stream transport to move (Parker and McCleave 1997). A proportion of juvenile eels migrate into freshwater, while others mature in estuaries.

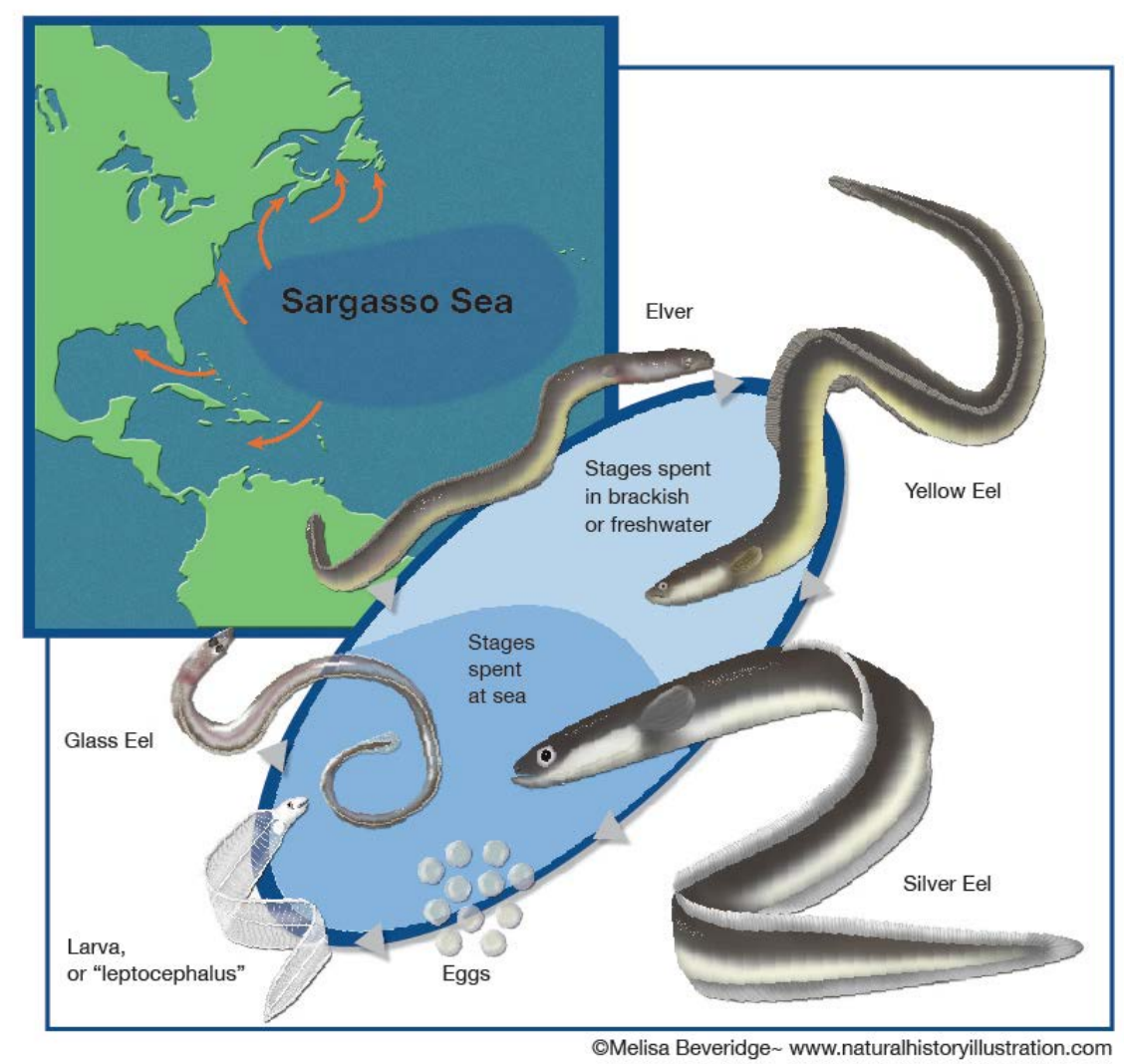

Fig. 1. Life cycle of the American eel, Anguilla rostrata” (C2013 Melisa Beveridge 3. RISK ASSESSMENT: AMERICAN EEL LISTING AND FUTURE HYDROPOWER PRODUCTION

Geographic overlap between eels and hydropower plants has significant implications for the hydropower industry and for conservation and commercial fishing for the American eel. These two perspectives raise the following questions: 
- How much hydropower capacity is at risk because of conservation concerns for American eel?

- How does hydropower development affect the current distribution of American eel habitat?

In this report, we used data from two sources to address these two related questions, the National Hydropower Assess Assessment Program (Hadjerioua et al. 2011) and NatureServe (NatureServe 2004). Details regarding data sources and processing are provided in section 3.3 below.

\subsection{HOW DOES AMERICAN EEL PRESENCE IMPACT HYDROPOWER?}

Listing of this species under the ESA could potentially impact hydropower projects totaling 32,719 MW of existing nameplate capacity. Hydropower plants most likely to be affected by eels occur in the Great Lakes / St Lawrence River basin, New England and the Mid-Atlantic states (black bars in Fig. 2, Fig. 3). There also are several larger plants at risk in the South Atlantic (Fig. 3).

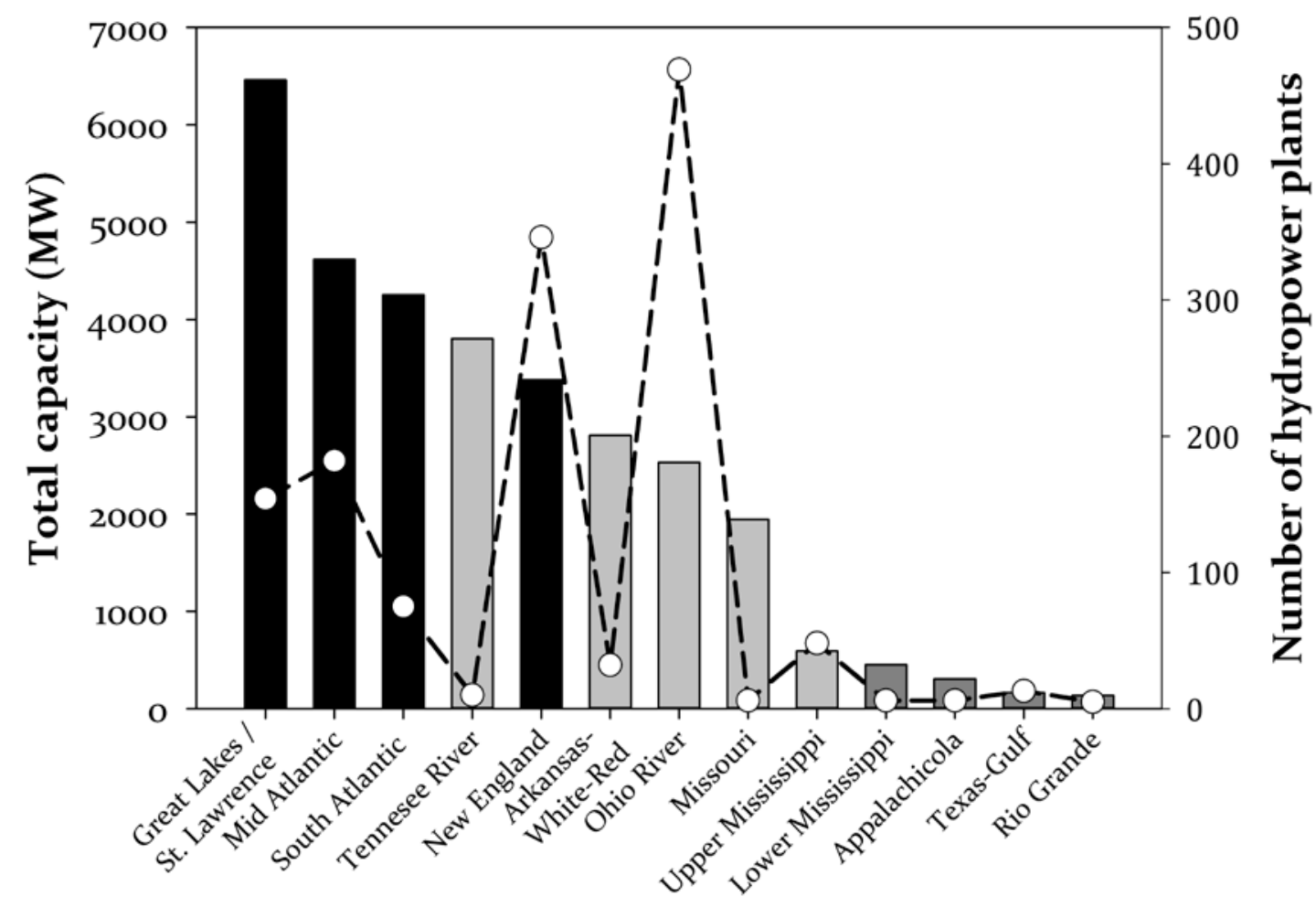

\section{River basin}

Fig. 2. Hydropower generation capacity at potential risk due to mitigation for the American eel.Black bars indicate estuaries and river basins with high eel abundances, dark-grey bars denote coastal estuaries with lower abundances, and light-grey bars denote interior Mississippi River drainages with even lower abundances. 


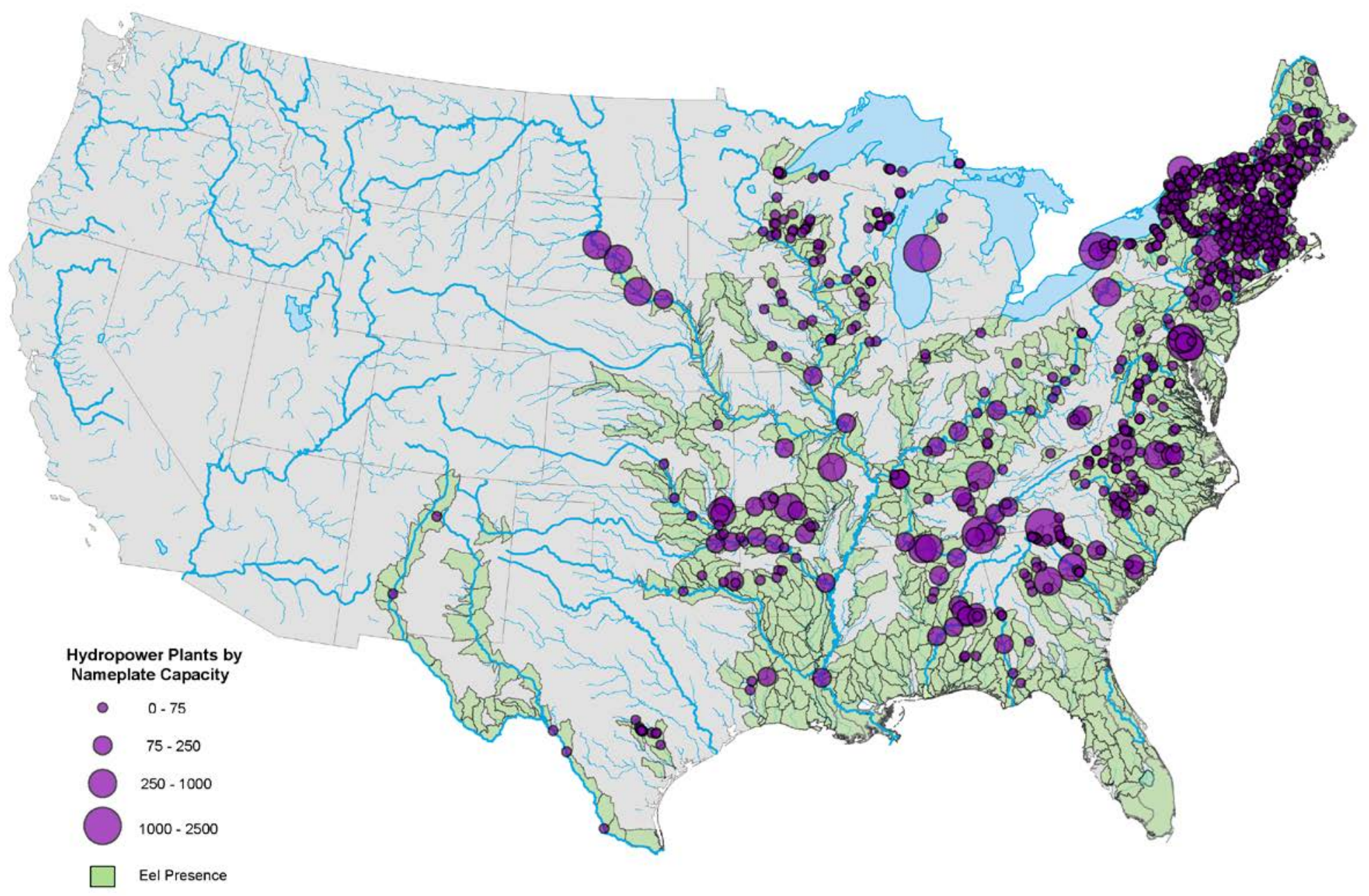

Fig. 3. ESA listing the American eel could impact 32,719 MW of nameplate capacity at 939 US hydropower plants. "Eel presence" identifies 8-digit USGS US river subbasins where eels are currently present or where they were historically present. 


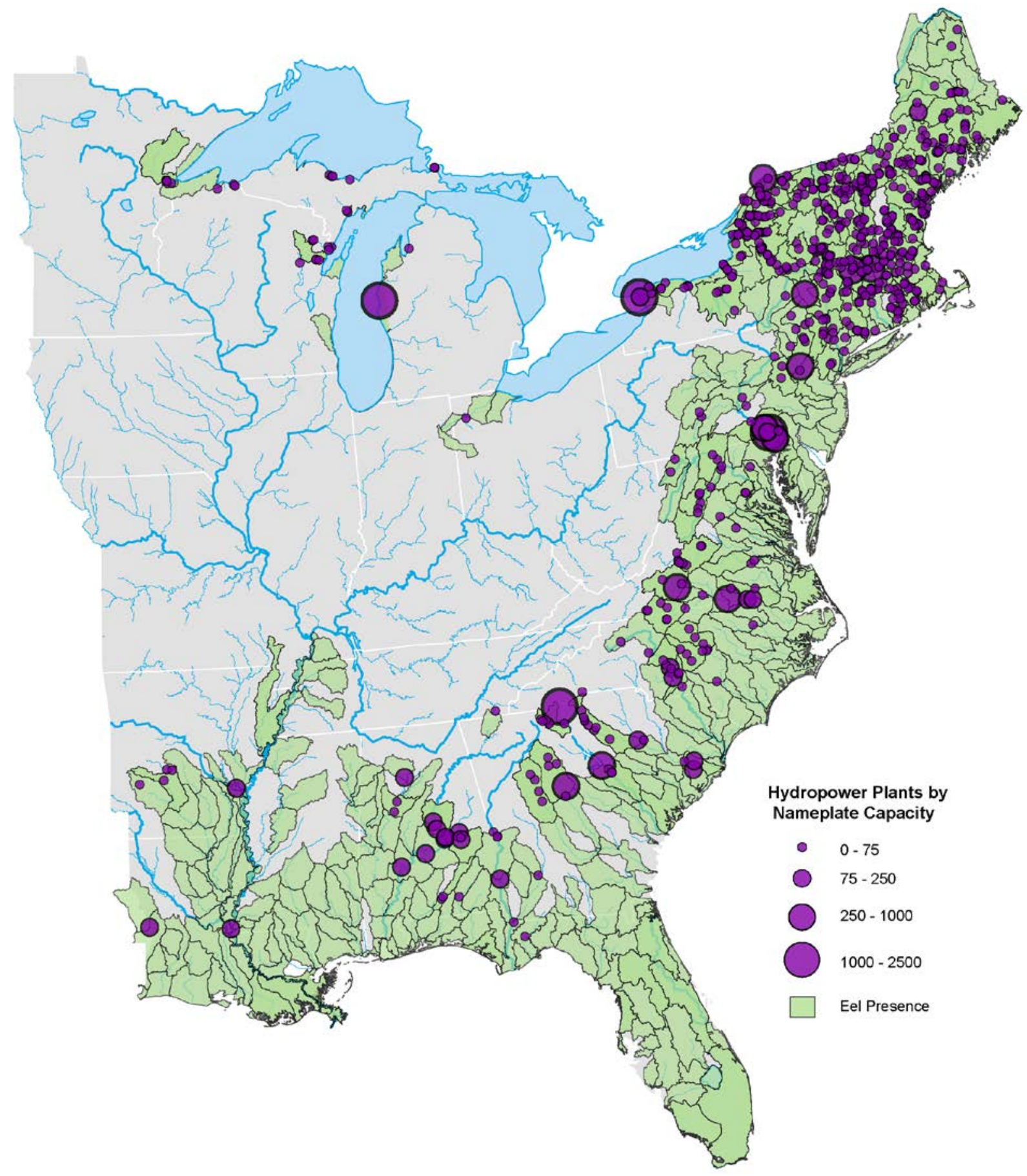

Fig. 4. ESA listing the American eel could impact 20,901 MW of nameplate capacity at 795 hydropower plants in coastal drainages. "Eel presence" identifies 8-digit USGS subbasins where eels are currently present or where they were historically present in coastal river basins of the United States. 
From the standpoint of eel abundance, the presence of dams has shifted the geographic distribution of eels. The highest eel abundances were historically in the St. Lawrence River. Juvenile eel abundance is now highest in the Chesapeake Bay (Potomoc River) and Hudson River (Table 1).

Table 1. Estimates of eel densities and biomass for studies of Atlantic coastal rivers and estuaries at a range of latitudes

\begin{tabular}{|c|c|c|c|c|}
\hline River/estuary & $\begin{array}{l}\text { Density } \\
\text { eels ha }^{-1}\end{array}$ & $\begin{array}{l}\text { Biomass } \\
\left(\mathrm{kg} / \mathrm{ha}^{-1}\right)\end{array}$ & $\begin{array}{c}\text { Year or season / lifestage } \\
\text { / habitat }\end{array}$ & Reference \\
\hline E. Machias R., ME & $21.8 \pm 9.0$ & $0.670 \pm 0.089$ & $\begin{array}{l}\text { Electroshocking river, } \\
>100 \text { mm yellow eels }\end{array}$ & $\begin{array}{l}\text { (Oliveira and McCleave } \\
\text { 2000) }\end{array}$ \\
\hline Pleasant R., ME & $8.4 \pm 3.1$ & $0.398 \pm 0.14$ & $\begin{array}{l}\text { Electroshocking river, } \\
>100 \text { mm yellow eels }\end{array}$ & $\begin{array}{l}\text { (Oliveira and McCleave } \\
\text { 2000) }\end{array}$ \\
\hline Sheepscot, ME & $10.8 \pm 1.1$ & $0.38 \pm 0.084$ & $\begin{array}{l}\text { Electroshocking, >100 mm } \\
\text { yellow eels }\end{array}$ & $\begin{array}{l}\text { (Oliveira and McCleave } \\
\text { 2000) }\end{array}$ \\
\hline Medomak, ME & $10.4 \pm 1.9$ & $1.485 \pm 0.697$ & $\begin{array}{l}\text { Electroshocking river, } \\
>100 \text { mm yellow eels }\end{array}$ & $\begin{array}{l}\text { (Oliveira and McCleave } \\
\text { 2000) }\end{array}$ \\
\hline Hudson River, NY & $5-18$ & $1.1-1.77$ & $\begin{array}{l}\text { Eel-pot sampling of } \\
\text { estuary }\end{array}$ & (Morrison and Secor 2003) \\
\hline Potomac R. & $230-256$ & $23.2-26.7$ & Summer, yellow eel & (Fenske 2009) \\
\hline Potomac R. & $79-83$ & $8.5-43.1$ & Fall, yellow eel & (Fenske 2009) \\
\hline $\begin{array}{l}\text { White Oak Estuary, } \\
\text { NC }\end{array}$ & $4-13.8$ & & $\begin{array}{l}\text { Eel-pot sampling of } \\
\text { estuary, >300 mm eels }\end{array}$ & $\begin{array}{l}\text { (Hightower and Nesnow } \\
\text { 2006) }\end{array}$ \\
\hline
\end{tabular}

A small fraction of juvenile eels migrate along the Florida Strait to rivers draining into Choctawhatchee Bay (e.g., the Apalachicola River) and the Mississippi River/Gulf of Mexico. At times, large numbers collect below Jim Woodruff Dam (Yerger 1977). Although non-Atlantic elvers represent a small fraction of the juvenile population, they may have disproportionately high demographic significance because nearly all elvers in the interior Mississippi River basin become females. Assets in the Mississippi River Basin and Gulf-coast drainages are included in Fig. 2 (grey bars) and on the map, Fig. 3.

\subsection{HOW DOES HYDROPOWER AFFECT AMERICAN EEL DISTRIBUTION?}

Hydropower can influence eels and other migratory species in three main ways: (1) by converting river habitat, (2) by blocking access to upstream freshwater habitat, and (3) by causing mortality during downstream migration.

Evidence suggests that going downstream past dams is far more dangerous than upstream passage for eels. Consequently, passing eels upstream is essentially luring them into an "ecological trap” because it exposes them to turbine and impingement mortality during downstream migration (Pelicice and Agostinho 2008). Upstream passage has not helped to recover most diadromous species (Brown et al. 2013), particularly on the Atlantic coast. It has even been suggested that the timing of the decline in some diadromous fishes, such as shad, may have coincided with the building of structures to pass fish upstream along the Atlantic coast.

A review of the habitat requirements of the American eel raises two questions about the role of hydropower: (1) Can eels thrive without access to freshwater?, and (2) Can eels can thrive in an impounded freshwater habitat? 


\subsubsection{Can eels thrive without access to freshwater habitat?}

Blocking of access to freshwater habitat is the first influence of hydropower on habitat. Historically, a significant fraction of eels migrated into freshwater to rear and mature before emigrating to spawn in the Sargasso Sea. Many eels now remain in the estuary and do not move inland (Morrison and Secor 2003). There is substantial evidence that more eels would move inland given the opportunity, as glass eels show a strong preference for migrating into freshwater (Sullivan et al. 2006). In addition, eel densities are high below dams lacking effective eel ladders and low in the stream networks above these dams, e.g., the Hudson River (Machut et al. 2007) and Conowingo Dam on the Susquehanna River (S.M. Eyler USGS, AFS 2013).

A population's viability is usually determined by its females. The contribution of one generation of individuals to the next is the sum of (fertilized) eggs produced by adult females that succeed in migrating to the Sargasso Sea to spawn. Female fecundities (eggs) increase with body size, as described by Eqs. (1) and (2):

$$
\begin{aligned}
& \log F=-4.29514+3.74418 \log T L, \text { and } \\
& \log F=3.2290+1.1157 \log W,
\end{aligned}
$$

where $F=$ number of eggs per female, $T L=$ total length $(\mathrm{mm})$, and $W=$ total weight $(\mathrm{g})$ (Wenner and Musick 1974) cited in American Eel Plan Development Team (1999).

One reason that freshwater access is important to the American eel population is that large females tend to emerge from juvenile eels that migrate farther inland, and these individuals contribute the most to the next generation (Gunning and Shoop 1962, Goodwin and Angermeier 2003, Davey and Jellyman 2005). Sex is determined, in part, by environmental factors, and as a general rule, more females are produced in habitats that engender slower growth (Cote et al. 2009). Wetlands, lakes, and ponds are also associated with higher production of females. Conversely, individuals remaining in estuaries develop into males at a higher rate and grow faster than those in freshwater (Morrison et al. 2002, Lamson et al. 2009). This may be because estuaries have higher densities (Oliveira et al. 2001, Oliveira and McCleave 2002). Therefore, this species appears to need access to inland habitat for at least some portion of its range to produce large, fecund females. Secondly, build-up of high juvenile densities below dams can inhibit production of females.

\subsubsection{Can eels thrive in impounded freshwater habitat?}

Eels are capable of thriving in a wide range of habitats. The question becomes whether a habitat generalist like the American eel is capable of thriving in regulated rivers. Changes in river habitat associated with impoundment are well known (Nilsson et al. 2005). Upstream of dams, free-flowing habitat and surrounding bottomlands become inundated. Loss of habitat is also associated with the use of canals and other artificial conveyances to carry flow in place of natural streams. Eels might benefit from a net increase in lacrustine (lake-like) habitat produced by hydropower development, as long as it is safely connected to the ocean and does not degrade water quality. Reservoir habitat could promote development of female eels (Cairns et al. 2004), but this has not been demonstrated. Loss of wetlands caused by conversion of land to urban and agricultural uses may also have negative effects on the eel population, and coastal development has impacted estuaries used by eels.

Because eels are habitat generalists, habitat models using micro-habitat variables (e.g., velocity, depth) show little ability to predict eel occupancy. However, models that included the distance from dams (Smogor et al. 1995, Wiley et al. 2004) and biotic factors (other fishes, other eels) were moderately 
successful in predicting eel abundances. Eels are nocturnal predators, and larger individuals (>400 mm) are cannibalistic (Jessop 2000, Oliveira et al. 2001), especially at higher densities. This explains the importance of other fishes and eels as predictors of eel habitat use. In addition, segregated habitat use (one tributary dominated by males and one by females), was observed in one Maine watershed (Oliveira et al. 2001). In the Hudson River, the presence of an upstream barrier and the number of downstream barriers were the best predictors of abundance (Machut et al. 2007). Physiological condition was also poorer among eels in reaches in urban watersheds (Machut et al. 2007). A habitat suitability model developed for eels in the Susquehanna River based on geology found weak positive associations of mudsiltstone and negative associations of carbonate geology with eel abundance (Kocovsky et al. 2008). Thus far, no studies have considered all of these predictors - including those related to connectivity and dams, substrate, fish and smaller eel densities, land use, and microhabitat-in one analysis.

Eels exhibit fairly broad tolerances for water quality parameters. Yellow eels are thought to enter torpor at temperatures below $8^{\circ} \mathrm{C}$ (Walsh et al. 1983). Generally, eels inhabit waters with dissolved oxygen concentrations in the range of $4-9 \mathrm{mg} \mathrm{L}^{-1}$ (Geer 2003). Eels in eel pots died when estuary bottom conditions fell below $1.5 \mathrm{mg} \mathrm{L}^{-1}$ (Fenske 2009). Contaminant uptake is also a concern. In particular, eels reared in freshwater live longer than those in the estuary (10-20 years, according to (Goodwin and Angermeier 2003)], which exposes this fraction of the population to contaminants for a longer time (Lamson et al. 2009).

To summarize, without the added risk of turbine mortality, eels may be capable of thriving (i.e., producing large females) in regulated rivers and they may even derive growth benefits from reservoir habitat as long as dissolved oxygen levels are adequate.

\subsection{SPATIAL DATA USED TO ASSESS EEL-HYDROPOWER INTERACTION}

The National Hydropower Assess Assessment Program (Hadjerioua et al. 2011) is a geospatial information system that provides integrated datasets describing the US fleet of hydropower assets in the context of water resources. The NHAAP includes a comprehensive inventory of baseline engineering and electricity generation capacity, from which we extracted information for existing power plants and megawatts produced by nameplate capacity. Geographic data describing the historical distribution of the American Eel was obtained from NatureServe (NatureServe 2004). Recorded occurrences of eel indicate a presence of the species within each subbasin (8 digit hydrological unit), as defined by the US Geological Society. The distribution of hydropower plants in the U.S. from the NHAAP database and the eel dataset from Nature Serve were overlaid using the "Spatial Join" feature in ArcGIS 10. This join allowed for totaling of all hydropower megawatts that overlapped with eel habitat, as well as isolating totals by hydrological region. 


\subsection{GOING UP-DAMS BLOCK ACCESS TO UPSTREAM FRESHWATER HABITAT}

\subsubsection{Change in geographic distribution}

Eels have lost access to most coastal river systems. Busch et al. (1998) estimated that fishes have lost access to $85 \%$ of freshwater habitat. Historical records show eels throughout the Mississippi River drainage, with females traveling farther inland and males remaining nearer brackish water (Gunning and Shoop 1962). However, most of the information on eel distributions and changes associated with dams comes from rivers on the Atlantic coast. Figure 5a-c illustrates dam-related changes in the access of eels to freshwater in US drainages along the Atlantic coast (Busch et al. 1998). Since this time, eel ladders have been added, increasing access of eels to interior rivers and exposing more assets.

\subsubsection{Spatial life-history variation}

Only a portion of eels migrate into freshwater permanently to rear, and those that remain in the estuary grow faster than those that succeed in reaching rivers. Others have been observed moving into freshwater during winter at high latitudes, but returning to the estuary in spring (Thibault et al. 2007a). It has been suggested that eels use freshwater as a refuge to avoid sub-zero temperatures in estuaries (Thibault et al. 2007b) at high latitudes. Migrations between estuary and brackish water in coastal rivers have also been observed. Movement upstream into freshwater can occur at different juvenile life stages: glass eel, pigmented elver, and yellow eel. 

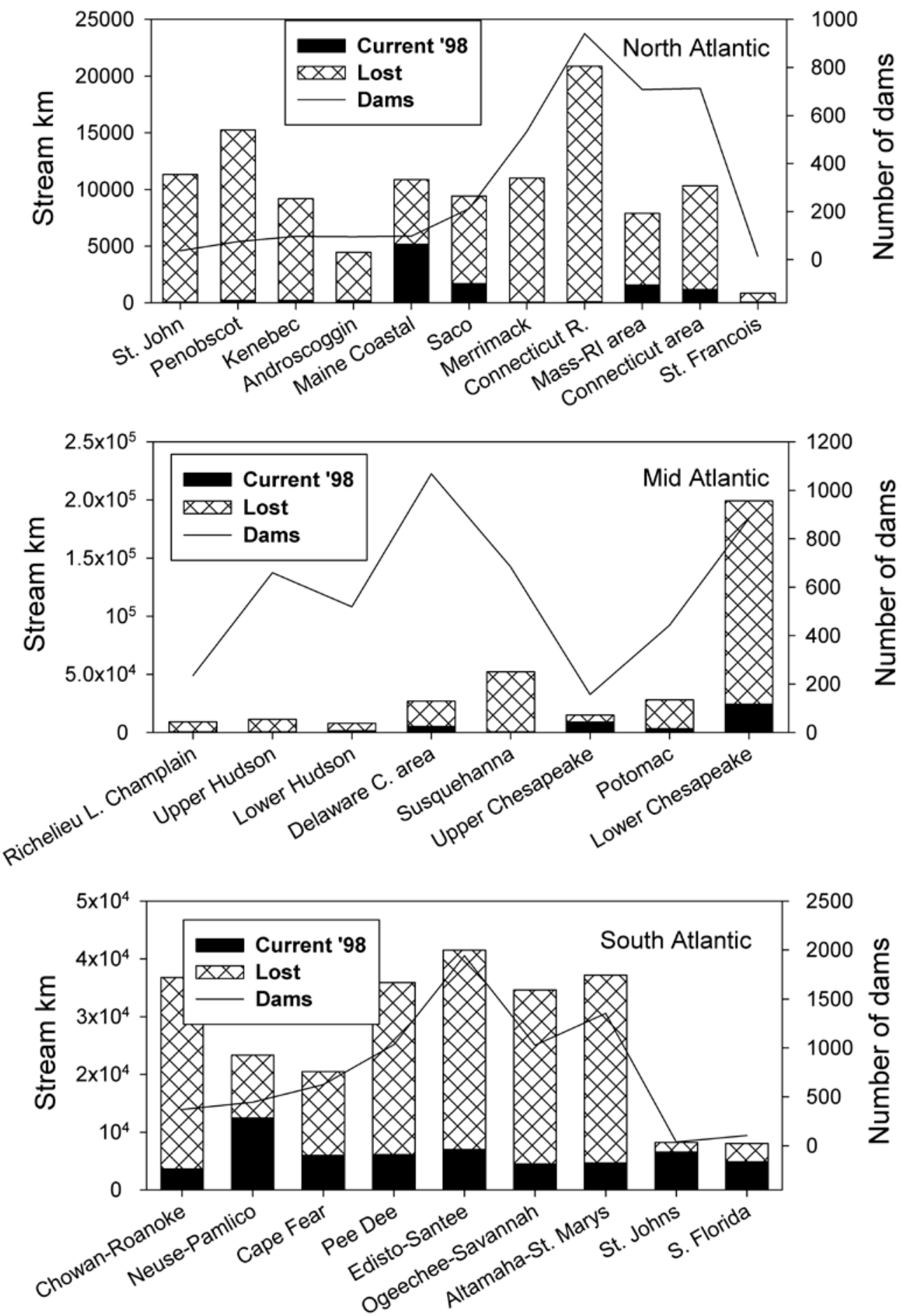

Fig. 5. Loss of freshwater habitat for the American eel. Source: Busch et al. (1998) This analysis assumed that all upstream habitat was historically available, regardless of natural barriers, and that the dams farthest downstream were impassable. 


\subsubsection{Timing of upstream migration}

Upstream migrations of juveniles into rivers along the North American Atlantic coast generally occur in spring. Glass eels migrate upstream after water temperatures reach the $10-15^{\circ} \mathrm{C}$ range, but they continue to migrate throughout summer. Similar patterns are found in Albemarle Sound, North Carolina (Overton and Rulifson 2009) and Rhode Island (Sorensen and Bianchini 1986). Migration of small glass eels was inhibited at high flows (Overton and Rulifson 2009). Yellow eels that migrate into freshwater also move in spring, triggered by rising temperatures starting at $14-16^{\circ} \mathrm{C}$, and peaking at $20^{\circ} \mathrm{C}$ (Verdon 2003). Use of eel ladders, mainly by smaller eels, was observed in spring when temperatures exceeded $12^{\circ} \mathrm{C}$ in a New York stream (Thibault et al. 2007b). In the St. Lawrence River, a second peak of activity occurred in early October (McGrath et al. 2003b). Eels are nocturnal predators. Consequently, they are more active at night than during daytime hours (Facey and Avyle. 1987), and eel migrations are usually nocturnal.

\subsubsection{Effects of barriers on abundances and size distributions}

Adding upstream passage or removing dams has resulted in increased numbers of eels, particularly smaller size and age classes, in previously blocked headwater sections of rivers. Conversely, the densities of small eels decreased below dams after ladders were installed (Thibault et al. 2007b, Schmidt et al. 2009). A recent study by Hitt et al. (2012) showed that eel densities doubled in headwaters up to $150 \mathrm{~km}$ upstream after removal of a dam in the Rappahannock River, Virginia. The increased density was primarily due to an increase in smaller eels, which were previously unable to ascend past the dam. However, overall eel biomass above the former dam site decreased. Regional trends in recruitment during this period were documented from eel densities in rivers and estuaries of other river basins monitored by the Maryland Stream Survey. The survey did not show changes in headwater eel densities, and estuary densities declined during the same period that eels increased in abundance in the Rappahannock River. Similar results were observed for the European eel after eel ladders were installed (Briand et al. 2005, Laffaille et al. 2005).

These studies provide evidence of a redistribution of juvenile eels between estuary and headwater habitats, but they do not demonstrate an overall benefit of upstream passage to the population. To demonstrate a potential demographic benefit, the next step would be to assess the future growth of ascending juveniles into large, fecund adult females that successfully migrate downstream. 


\subsection{GOING DOWN-IMPINGEMENT, ENTRAINMENT, AND SPILL}

Successful downstream migration of adult eels, particularly large females, is important to eel population growth. We view the likelihood of survival downstream as the outcome of a multi-step binary decision tree (Fig. 6). Increasing the likelihood that silver eels will use less-risky pathways through the dam is the goal, and moving toward the goal involves implementing less risky options during peaks in migration.

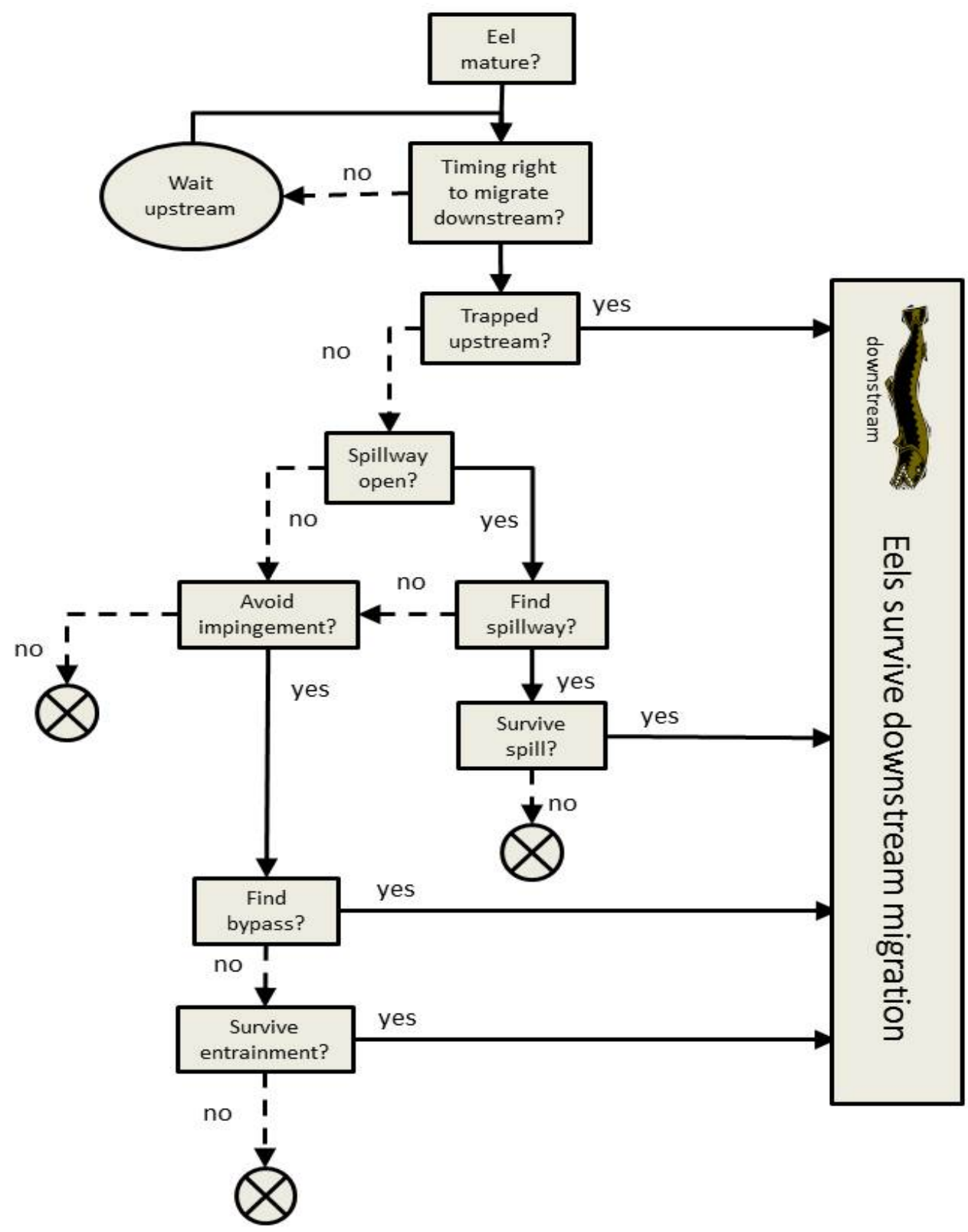

Fig. 6. Decision process for survival of adult eels migrating downstream from freshwater to ocean. Probabilities of survival can be assigned at each split for a given hydropower project. 


\subsubsection{Timing of downstream migration by silver eels}

Understanding the factors that control the timing of maturation and downstream migration of silver eels might restrict the window during which downstream passage and other protective measures would be needed. The onset of maturation is a necessary, but not sufficient, condition for migration. Migration is initiated by individuals who are beginning the process of maturing from yellow (immature) to silver (maturing) eels. Silver eels become fully mature during their ocean migration.

Downstream migration of American eels generally occurs in the fall (Richkus and Dixon 2003), although occasionally individuals migrate in spring. The best evidence suggests that a lower threshold temperature defines the start of downstream migration in the fall (Richkus 2001), but no specific temperature threshold has been identified. However, eels stop moving at temperatures below $10^{\circ} \mathrm{C}$ and orient away from light toward deeper waters (Haro 1991). Although some studies suggest that migration is triggered by sudden drops in temperature (Durif et al. 2003), this is not always the case.

One of the most reliable patterns is that eels move at night and rest during the day (Haro et al. 2000a). The moon phase influences nocturnal migration. One study found higher catches during last-quarter and new moons (McGrath et al. 2003a). One hypothesis is that eels are inhibited from moving by the amount of light cast during a fuller moon (Richkus and Dixon 2003), but this idea was contradicted by a study of migration patterns in the St. Lawrence River (Cairns and Hooley 2002).

There is some evidence that rainfall, or another factor correlated with rainfall, stimulates pulses of downstream migration. For example, rainfall stimulated migration in two New Zealand eel species (Watene et al. 2003). One hypothesis is that this relationship may be mediated by turbidity. Downstream movements of radio-telemetered American eels were stimulated by increases in turbidity following rainfall and ceased when the water cleared (Durif et al. 2003). A second hypothesis points to decreases in air pressure.

Permitting spills, particularly through deep gates, during rainfall at night and within the fall period of peak migration, may be a reasonable option for increasing the proportion of silver eels surviving downstream migration.

\subsubsection{Pathways through the hydropower system}

Eels migrating downstream past dams encounter potential risks and barriers, including impingement on screens, entrainment into turbines, or spill. Because eels have an elongated body shape and show atypical behavioral responses, barriers should ideally be designed to minimize the risk of both impingement and entrainment. This section discusses each of these risks.

Impingement. Screens, louvers, and trash bars are structures that protect turbines from large objects and prevent entrainment of some larger individuals of fish species, such as sturgeon. Whereas visual-feeding fishes that are good swimmers avoid contact with these structures when possible (i.e., at lower flows), non-visual fishes, including eels, that are poor swimmers are unable to react until they physically encounter the structures. Eels that encounter obstacles at turbine intakes can be injured at high flows. For example, a study at a Swedish hydropower plant (Calles et al. 2010) estimated turbine strike mortality and impingement mortality separately for silver eels. Approach velocities for this study ranged between 0.93 and $1.17 \mathrm{~m} \mathrm{~s}^{-1}$. Impingement of tagged eels averaging $737 \mathrm{~mm}$ in length on $20-\mathrm{mm}$ trash racks angled at $63.4^{\circ}$ contributed an additional 35\% mortality over that attributed to other factors and many non-tagged eels were cleaned off the racks (Calles et al. 2010). 
Entrainment. Turbine-related mortality is the primary concern for American eels migrating downstream to sea through dams. Injuries to silver eels caused by mechanical strike far outweigh the effects of other factors, such as pressure flux and shear (Richkus and Dixon 2003). Because of their elongated bodies, high percentages of adults are injured in passing through small propeller turbines with high rotation speeds (Richkus and Dixon 2003). Mortality rates for adult eels are 4 to 5 times higher than those for juvenile salmonids (Larinier and Travade 2002).

Telemetry studies have reported a wide range of turbine mortality rates, depending on turbine type, river flow, and eel size. Mortality risk is higher for larger eels. The chance of encountering a turbine blade is proportional to the ratio of total fish length to the distance between blades (Hadderingh and Bakker 1998). This relationship is well-supported by field experiments. As one example among many, a study of European eels estimated that 25 to $32 \%$ of shorter $(40-90 \mathrm{~cm})$ eels but $60 \%$ of eels longer than $90 \mathrm{~cm}$ were killed by turbines at hydropower projects in the Meuse River (Jansen et al. 2007).

It has also been reported that mortality risk is higher at lower flows (Bruus et al. 2009), possibly because the duration of exposure to blade strike is shorter at higher flows. A declining exponential relationship between strike risk and flow was quantified for silver European eels averaging 50 to $65 \mathrm{~cm}$ passing through one of four horizontal bulb turbines at two hydropower plants on the Meuse River (Jansen et al. 2007). Such a relationship was also reported by Hadderingh and Bakker (1998). However, a review by (Richkus 2001) found exceptions to this proposition. In addition to a possible effect of flow on strike risk, higher flows may increase access to safer migration routes, most notably via spillways. Different route options were responsible for lower mortality rates at a higher flow (100 $\mathrm{m}^{3} \mathrm{~s}^{-1} ; 7$ to $\left.12 \%\right)$ than at a lower turbine flow ( $25 \mathrm{~m}^{3} \mathrm{~s}^{-1,}$ near 25\%) at two Meuse River projects (Jansen et al. 2007).

Turbine design can also influence mortality rates. Among turbine designs currently deployed, horizontal bulb turbines may produce the highest survival rates for eels because they have fewer blades and the distance between guide vanes and fewer runner blades than vertical turbines (Hadderingh and Bakker 1998). On the Meuse River, Winter et al. (2007) estimated that direct mortality for silver eels passing through horizontal Kaplan-bulb turbines was between 16 and 34\%. This study also accounted for competing risks including fishing mortality. In turbine testing at a hydropower plant on the St. Lawrence River, eels averaging $885-\mathrm{mm}$ suffered $23.9 \%$ mortality after one day when entrained through a propeller turbine, but only 15.8\% mortality when entrained through a Francis turbine (Richkus 2001). Larinier and Travade (2002) reported mortality rates of 15 to 30\% for large, low-head Kaplan turbines and much higher rates (50-100\%) for smaller turbines suitable for small, low-head plants (Hadderingh and Bakker 1998).

One New Brunswick study was conducted at a 15-MW project with two Kaplan variable-pitch propeller turbines, an eel ladder and a bypass centered between two intakes. Of twenty-five $>75$-cm silver eels tagged and released 1-km above the dam, all 19 that passed through turbines died, whereas the remaining six following other routes (either a bypass chute, spillway or fish ladder) survived (Carr and Whoriskey 2008). A study at a Swedish plant with three twin-Francis turbines measured mortality rates of silver eels (average length $737 \mathrm{~mm}$ ) via different routes. When exposed only to turbine strike, mortality was 60\%, (Calles et al. 2010).

Spillway passage. Eels are successfully passed downstream through spillways and sluices, particularly those accessible to bottom-oriented fishes. The US Fish and Wildlife Service recommends minimum spill flows of 0.2 to 0.5 cfs for every square mile of drainage in the northeastern US (Haro et al. 2003). Passage through spillways can lead to mortality under certain conditions, but these conditions can be avoided by proper design. Significant damage to fish occurs when the impact velocity on the water surface exceeds a critical velocity of 15-16 m s$~^{-1}$ (Larinier and Travade 2002). Critical velocity is reached during falls from shorter spillway heights for longer fish, and the risk of significant injury increases rapidly once heights 
exceed 13 m, with 100\% mortality for a drop of 50 to $60 \mathrm{~m}$ (Larinier and Travade 2002). In one study, European eels released in the reservoir that passed through a former channel via spill experienced $17 \%$ mortality at a dam with a head of $23.5 \mathrm{~m}$ (Calles et al. 2010).

Bypass structures. Other types of bypass structures have had modest success with passing eels downstream because eels have trouble finding them. Guiding eels away from turbine intakes and toward bypasses involves special design considerations that are not required for other fish species. For example, bottom bypasses have generally been more successful than surface ones because eels are bottom oriented fishes (Gosset et al. 2005). In some studies, the percentage of eels using bypass structures was roughly approximated by the percentage of flow (Richkus and Dixon 2003, Jansen et al. 2007), which suggests that guidance had not been effective. Mechanical barriers, including angled bar racks, louvers, and screens, have been less successful for eels than for other fishes. Eels respond to barriers by trying to force their way through after physically bumping into them (Richkus and Dixon 2003). A number of guidance options, including attraction and repulsion technologies, have been tested at small scales (Versar 2009). However, most guidance options remain infeasible for larger rivers anddams.

\section{SOLUTIONS}

Research has been conducted to explore technical solutions to the problems that hydropower dams cause for migratory eels. This section documents the successes and the failures in providing up and downstream passage for eels. In addition, we step back and explore new, untested ideas, some of which may turn out to be valuable. As a general rule, our review suggests that single mitigations implemented in isolation are likely to fail, but that combinations of mitigation options lead to success (Coutant 2001). This report attempts to highlight how these options can be combined effectively.

\subsection{GOING UP (UPSTREAM PASSAGE)}

A portion of juvenile (yellow) eels remain in estuaries, whereas others migrate upstream to freshwater rearing habitat. It is during this upstream migration that they first encounter dams and other barriers.

Two options for facilitating upstream movement are volitional passage using eel ladders and trap-andtransport programs. Trap-and-transport could be more costly for this species, but it has advantages. One advantage is as a temporary strategy for ensuring that moving eels upstream will provide a demographic benefit to the overall population. As a long-term option, upstream translocation can permit moving individuals farther upstream without passing multiple dams.

Eel ladders (Fig. 7), flumes placed at a 5 to $45 \%$ angle (Porcher 2002), are a second option for moving juvenile eels upstream past dams. Eels are better able to make use of upstream passage facilities than most other fish species. Eel ladders can achieve 40 to $60 \%$ efficiency in passing yellow eels upstream (Verdon et al. 2003). The ladder at Moses-Saunders Dam passed 47 to $79 \%$ of eels that entered it (McGrath et al. 2003b). The range of sizes that used the eel ladder at Moses-Saunders Dam was 126 to $834 \mathrm{~mm}$ (average $400 \mathrm{~mm}$ ) (McGrath et al. 2003b). Smaller yellow eels tend to use the ladders more than medium-sized eels, and large eels do not (Schmidt et al. 2009). This difference is thought to be a result of densitydependent pressure on small eels to avoid larger ones below dams, particularly when downstream densities are high (Schmidt et al. 2009). Glass eels and elvers are less able to navigate to ladders (Bult and Dekker 2007). 


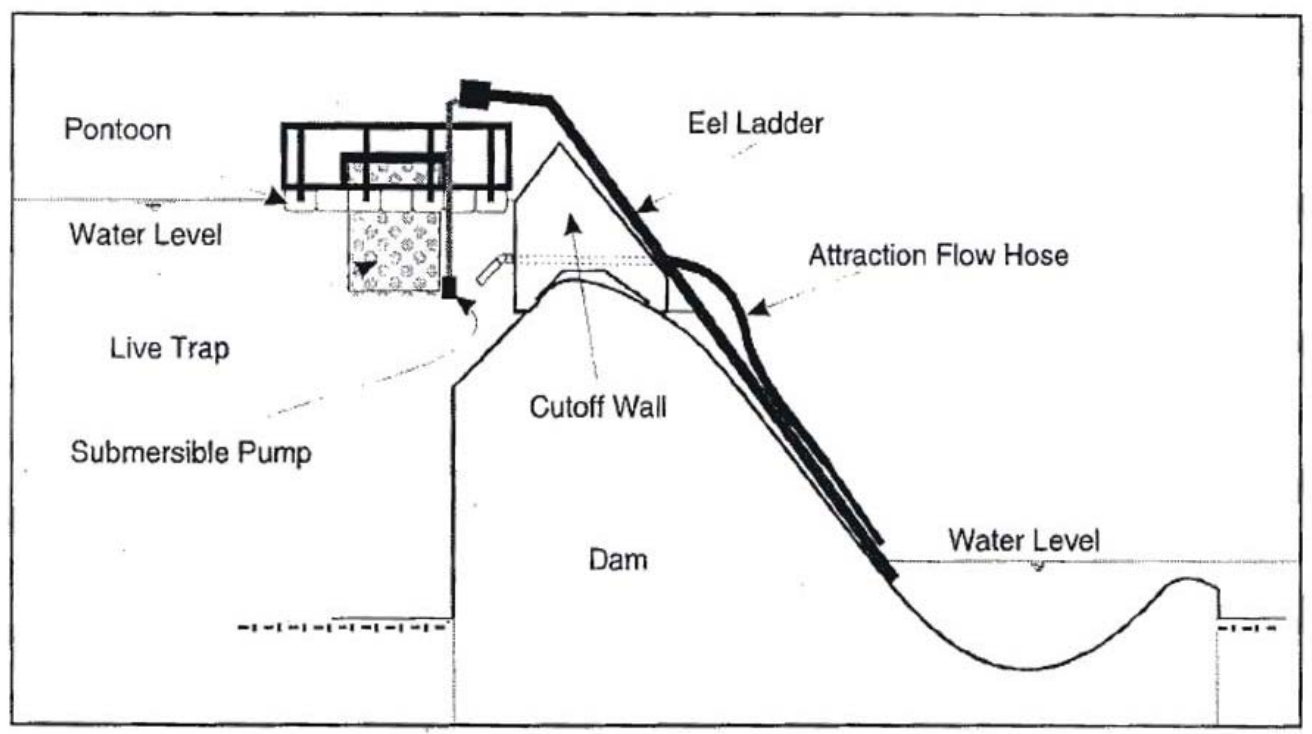

Fig. 7. Cross-section of the eel ladder on Chambly Dam (Verdon 2003).

Eels are unique among fishes, and understanding their biology is important. For example, passage programs and structures should mitigate the effects of high eel densities on cannibalism (DeLeo and Gatto 1996) by avoiding situations in which large and small eels are collected together for long times. Similarly, translocation or stocking programs should avoid producing high densities upstream because fewer females will then be produced.

In the following sections, we review what has worked, what has not worked, and ideas that have not been fully tested.

\subsubsection{What has worked}

- Monitoring success at each of three aspects of upstream passage: attraction, entry, exit (Bunt et al. 2012)

- Constructing eel ladders with wide entrances and roughened internal surfaces (McGrath et al. 2003b)

- Providing sufficient flow to wet the ladder's surface, moderate ladder temperature, and remove wastes, but not enough flow to impede the upstream progress of eels (McGrath et al. 2003b)

- Providing attraction flows near the ladder’s downstream entrance (Porcher 2002).

- Timing attraction flows to coincide with migrations of yellow eel upstream in spring and at night.

- Placing eel ladder entrances away from turbulent flows in the mid-channel (McGrath et al. 2003b)

- Placing eel ladder exits far from turbine intakes to prevent fallback (i.e., subsequent entrainment into turbines) (Verdon et al. 2003, McGrath et al. 2009, Stuart et al. 2010)

- Placing eel ladder exits away from turbulent and high flows in the forebay (Verdon et al. 2003) 
- Designing eel ladder exits that encourage eels to exit rather than pile up and block later-arriving eels (Richkus and Whalen 1999)

- Collecting eels in submerged collection nets on a platform below the upstream exit (McGrath et al. 2003b)

\subsubsection{What has not worked}

- Providing flow to ladders based on predicting the upstream movement of yellow eels based on moon phase, rain, or tidal phase (There is no correlation of movement with temperature, flow or lunar phase, but there is a possible connection with increasing temperature).

- Ladders with upstream outlets that permit eels to congregate near the exit and block others from exiting (Richkus and Whalen 1999). Eels are cannibalistic (DeLeo and Gatto 1996), and larger yellow eels may forage on incoming glass eels.

- Ladders with upstream outlets too close to the dam and turbine intakes (McGrath et al. 2009, Stuart et al. 2010). These result in fallback (entrainment of eels into turbines) or impingement. At MosesSaunders Dam on the St. Lawrence River, fallback rates were between 6 and 12\% (McGrath et al. 2003b).

- $\quad$ Ladders that slow migration or harm eels by reaching extreme temperatures.

- $\quad$ Ladders are not very effective for glass eels rely on selective tidal transport to navigate.

\subsubsection{What has not been tested}

- Upstream passage technologies, such as siphon systems, to improve passage for glass eels, which are less-able to navigate to ladders (Bult and Dekker 2007).

- Technologies for moving eels away from upstream ladder exits

0 Creating an area in the forebay near the exit of lower velocity below eel burst speeds ( $>1.5$ to 2.0 $\mathrm{m} / \mathrm{s}$ ) to reduce the risk of entrainment (fallback) (McGrath et al. 2009)

o A combination of collection of eels at ladder exits in submerged nets and guidance structures to move eels away from the forebay following collection

- Adaptive reconnection (Jager et al. in review)

\subsection{GOING DOWN (DOWNSTREAM PASSAGE)}

Facilitating downstream movement past dams is a key challenge for project owners in rivers that support eels. The three main approaches are to trap and transport downstream migrating silver eels, to provide passage through spillways, and to guide fish to bypass structures.

One mitigation measure used to help eels avoid mortality during downstream migration is to transport silver eels around dams after capturing them in upstream reservoirs using fyke nets (Boubee et al. 2003), traps (Durif et al. 2003), or weirs. This is referred to as "trap-and-transport". 
The trap-and-transport and bypass options both require some mechanism for guiding fish toward a particular downstream route or collection facility. Silver eels are widely dispersed at a range of depths and across the width of rivers (channel and margins) as they approach dams during outmigration (Versar 2009). Thus concentrating and collecting eels remains a considerable challenge, especially in large river systems. Silver eel collection at upstream locations are more-likely to succeed [e.g., trawling (McGrath et al. 2003a)] than efforts to collect eels in the forebay.

A theme running throughout the literature is that combinations of technologies are needed to successfully implement downstream passage (Coutant 2001).

\subsubsection{What has worked}

\section{- Trap-and-transport}

o Capture of downstream-migrating silver eels is more feasible in smaller rivers than in large rivers.

o In the St. Lawrence seaway, an upstream non-power dam is being considered as a location for collecting downstream migrants (C. Coutant, personal communication to H. Jager 9/15/2013)

\section{- Spillway passage}

o An open deep gate (Watene et al. 2003) and a range of depths (Haro et al. 2000b) can be used to improve chances that eels will find spillways. (Bottom bypass is 2 to 3 times more efficient than surface bypass because eels swim at the surface but dive when encountering dams.)

0 A low spillway opening height, $<13 \mathrm{~m}$ will reduce injury during spill (100\% mortality has been observed at heights $>50 \mathrm{~m}$ ) (Larinier and Travade 2002).

o A "ski-jump" design will help eels to avoid abrasion on the spillway face (Larinier and Travade 2002).

o Moderate spillway flows reduce injury (Larinier and Travade 2002).

o A deep stilling basin with no structures below can prevent injury (Larinier and Travade 2002, Watene and Boubee 2005).

\section{- Bypass structures—mechanical barriers}

o Mechanical barriers guiding eels to bypass structures are successful only in smaller rivers where flows are sufficiently low, and then only when combined with other options.

o Eels are more likely to find bottom structures than surface structures (Durif et al. 2003), in part because surface structures become clogged.

o Angled wire-mesh screens are more successful than other types of barriers because the risk of impingement is lower. Current flow pushes eels up the smooth surface to a bypass located at the farthest extremity of the screen (Richkus and Dixon 2003).

o Trash rack bars can be spaced to protect fine-mesh screens (Richkus and Dixon 2003), but this increases the risk of eel impingement. 
o Full-depth louver arrays with no space between the array and bypass bottom effectively guide American eels at Holyoke Dam (Ducheney et al. 2006)

o Positioning angled bar racks or louvers at a slight angle $\left(15^{\circ}\right)$ to the current helps avoid impingement while guiding eels to a bypass or trap (EPRI (Electric Power Research Institute) 2001, Amaral et al. 2002, Larinier and Travade 2002).

0 Reducing flow velocities across the faces of screens helps avoid impingement (<eel burst speed of $1.5-2.0 \mathrm{~m} / \mathrm{s}$ ). Eels are easily impinged against the structures except at low velocities (Richkus and Dixon 2003). According to Adam and Schwevers (1997), approach velocities of less than 0.5 $\mathrm{m} / \mathrm{s}$ are required to avoid impingement on angled screens. It has been suggested that the flow through a bypass structure should exceed that at intake trash racks and at least $5 \%$ of total river flow (Richkus and Dixon 2003).

\section{- Bypass structures-behavioral guidance}

o Strobe lights can be an effective way of guiding eels toward bypass structures, based on the aversion eels have for light (Patrick et al. 2001).

o Infrasound has been shown to influence silver eel movements (Sand et al. 2001).

o Reduced nighttime generation can be cost-effective because electricity has a lower value at night and eels tend to migrate downstream at night [(Bozeman et al. 1985, Haro et al. 2000b); 50\% of migration occurs between 23:00 and 2:00 (Verdon 2003)].

\section{- Turbine survival}

o Once eels are entrained, horizontal bulb turbines and large, low-head turbines have a lower risk of causing strike mortality than other turbines (Larinier and Travade 2002).

\subsubsection{What has not worked}

\section{- Trap and transport}

o Collection of silver eels in large rivers has proved difficult.

\section{- Spillway passage}

o Spilling water with high flows and no stilling basin below can cause mortality (Larinier and Travade 2002)

\section{- Bypass structures-mechanical barriers}

o Perpendicular barriers to prevent entrainment cause impingement ( $>15^{\circ}$ and without an overlay).

o Bypasses with limited flow fail to attract eels.

o Bar spacing has limited value as a mitigation option because it is flow dependent (wide spacing is needed at high flows to prevent impingement; narrow spacing is needed at low flows to prevent entrainment). 
- Bypass structures--behavioral guidance

o Behavioral avoidance barriers using bubble curtains (Haro et al. 2000b).

- Turbine survival

o Small-diameter, high-head turbines (e.g., Pelton turbines) (Larinier and Travade 2002).

\subsubsection{What has not been tested}

- Defining a narrow window during which to restrict operations while opening deep spill-gates could depend on the following cues within the fall period of peak migration:

o When downstream-migrating American eels accumulate above a dam, as detected by hydroacoustic or sonar imaging (Boubee and Williams 2006, Mueller et al. 2008)

o During rainfall and at night (Larinier and Travade 2002, Boubee and Williams 2006)

o The use of pulse flows to stimulate eel down-migration and concentrate movement during a narrower temporal window

- Advanced methods for successfully collecting silver eels during downstream migration and transporting or bypassing them downstream below dams

o Collection from smaller upstream reaches where guidance is feasible

o The use of chemical attractants (eel odor) (Briand et al. 2002)

o Guidance of eels using induced flow (vertical eel movements may be ‘exploration' for higher velocity pathways) 


\section{FUTURE RESEARCH DIRECTIONS}

Based on this review, we have identified key research needs to provide guidance to the hydropower industry regarding lowered exposure to future mitigation costs.

- Refine geographic assessment of projects at risk using FERC-license-scavenging to identify dams with upstream passage for eels and for other species to determine where upstream projects are at risk, including turbine, bypass, and spillway characteristics that influence survival of downstream passage.

- Evaluate potential for developing safer eel-friendly turbines and screening/guidance structures. Survival of turbine passage is currently so low that potential for improved outcomes is high.

- Evaluate seasonal impacts on generation based on river flows and the timing of downstream eel migration.

- Develop an on-line guidance tool for owners on the feasibility of alternative upstream and downstream passage options based on project characteristics, within a HydroGIS framework.

- Assess potential impacts of eel listing to future new hydropower development, including projects using irrigation canals.

- Estimate how effective downstream passage would need to be ("target survival”), to ensure that upstream passage would benefit eels. Given the strong density-dependence characteristic of this species, target survival may be relatively low.

- $\quad$ Evaluate population models available for eels (NIMBioS eel modeling workshop).

- Conduct eel research to characterize density-dependent habitat capacities. Characterize relationships between eel density and growth, survival, and sex-determination. These relationships are needed to evaluate survival targets for downstream passage.

- Evaluate the following options to see if this target survival could be met through adaptive reconnection:

- Collection of downstream-migrating silver eels at upstream non-power dams to bypass multiple hydropower projects, an option being considered in the St. Lawrence River (J. Gerlach, NYPA personal communication to H. Jager 9/2013).

o Combinations of technologies to provide downstream guidance to bypass structures

o Night-time low-gate spill during a window of migration narrowed by predictive models and acoustic sonar monitoring

- Conduct an economic cost-benefit analysis to identify approaches that meet the survival target with minimal impact on producers. Include trap-and-transport programs in this assessment.

- Address multi-species passage. How can existing passage structures be modified to accommodate eels, and are there other species that would benefit (e.g., benthic fishes such as sturgeons)?

- Conduct laboratory research to develop more-effective upstream passage options for glass eels. 


\section{ACKNOWLEDGEMENTS}

This research was supported by the Department of Energy Energy Efficiency and Renewable Energy, Wind and Waterpower Office. We appreciate editing assistance from Deborah Counce and Leslie Lauder. Dr. Charles Coutant (Coutant Aquatics, retired ORNL) provided us with reports and reviewed this document. We thank Jeff Gerlach (NYPA), and Douglas Dixon (EPRI) for providing seminal reports reviewing the effects of hydropower and the biology of eels. 


\section{REFERENCES}

Adam, B. and D. U. Schwevers. 1997. Behavioral Surveys of Eels (Anguilla anguilla) Migrating Downstream under Laboratory Conditions. Institute of Applied Ecology, Kirtorf-Wahlen, Germany.

Amaral, S. V., F. C. Winchell, B. J. McMahon, and D. A. Dixon. 2002. Evaluation of angled bar racks and louvers for guiding silver phase American eels. Pages 367-376 in D. A. Dixon, editor. Biology, Management, and Protection of Catadromous Eels. Amer Fisheries Soc, Bethesda.

Bonhommeau, S., E. Chassot, B. Planque, E. Rivot, A. H. Knap, and O. Le Pape. 2008. Impact of climate on eel populations of the Northern Hemisphere. Marine Ecology Progress Series 373:71-80.

Boubee, J. A. T., B. Chisnall, E. N. Watene, E. Williams, D. Roper, and A. Haro. 2003. Enhancement and management of eel fisheries affected by hydroelectric dams in New Zealand. Pages 191-205 in D. A. Dixon, editor. Biology, Management, and Protection of Catadromous Eels. American Fisheries Society, Bethesda, MD.

Boubee, J. A. T. and E. K. Williams. 2006. Downstream passage of silver eels at a small hydroelectric facility. Fisheries Management and Ecology 13:165-176.

Bozeman, E. L., G. S. Helfman, and T. Richardson. 1985. Population size and home range of American eels in a Georgia tidal creek. Transactions of the American Fisheries Society 114:821-825.

Briand, C., D. Fatin, G. Fontenelle, and E. Feunteun. 2005. Effect of re-opening of a migratory pathway for eel (Anguilla anguilla, L.) at a watershed scale. Bulletin Francais De La Peche Et De La Pisciculture:67-86.

Briand, C., D. Fatin, and A. Legault. 2002. Role of eel odour on the efficiency of an eel, Anguilla anguilla, ladder and trap. Environmental Biology of Fishes 65:473-477.

Brown, J. J., K. E. Limburg, J. R. Waldman, K. Stephenson, E. P. Glenn, F. Juanes, and A. Jordaan. 2013. Fish and hydropower on the US Atlantic coast: failed fisheries policies from half-way technologies. Conservation Letters 6:280-286.

Bruus, M. C. M., R.H. Hadderingh, U. Schwevers, B. Adam, U. Dumont, and H. V. Winter. 2009. Managing human impact on downstream migrating European eel in the River Meuse. Pages 381390 in J. M. Casselman and D. K. Cairns, editors. Eels at the edge. American Fisheries Society, Bethesda, MD.

Bult, T. P. and W. Dekker. 2007. Experimental field study on the migratory behaviour of glass eels (Anguilla anguilla) at the interface of fresh and salt water. Ices Journal of Marine Science 64:1396-1401.

Bunt, C. M., T. Castro-Santos, and A. Haro. 2012. Performance of fish passage structures at upstream barriers to migration. River Research and Applications 28:457-478.

Busch, W. D. N., S. J. Lary, C. M. Castilione, and R. P. McDonald. 1998. Distribution and availability of Atlantic coast freshwater habitats for American eel (Anguilla rostrata). . U.S. Fish and Wildlife Service, Amherst, New York.

Cairns, D. K. and P. J. D. Hooley. 2002. Lunar cycles of American eels in tidal waters of the Southern Gulf of St. lawrence, Canada. Pages 265-274 in D. A. Dixon, editor. Biology, Management, and Protection of Catadromous Eels. Amer Fisheries Soc, Bethesda.

Cairns, D. K., J. C. Shiao, Y. Iizuka, W. N. Tzeng, and C. D. MacPherson. 2004. Movement patterns of American eels in an impounded watercourse, as indicated by otolith microchemistry. North American Journal of Fisheries Management 24:452-458.

Calles, O., I. C. Olsson, C. Comoglio, P. S. Kemp, L. Blunden, M. Schmitz, and L. A. Greenberg. 2010. Size-dependent mortality of migratory silver eels at a hydropower plant, and implications for escapement to the sea. Freshwater Biology 55:2167-2180.

Carr, J. W. and F. G. Whoriskey. 2008. Migration of silver American eels past a hydroelectric dam and through a coastal zone. Fisheries Management and Ecology 15:393-400. 
Cote, C. L., M. Castonguay, G. Verreault, and L. Bernatchez. 2009. Differential effects of origin and salinity rearing conditions on growth of glass eels of the American eel Anguilla rostrata: implications for stocking programmes. Journal of Fish Biology 74:1934-1948.

Cote, C. L., P. A. Gagnaire, V. Bourret, G. Verreault, M. Castonguay, and L. Bernatchez. 2013. Population genetics of the American eel (Anguilla rostrata): FST $=0$ and North Atlantic Oscillation effects on demographic fluctuations of a panmictic species. Molecular Ecology 22:1763-1776.

Coutant, C. C. 2001. Integrated, multi-sensory, behavioral guidance systems for fish diversions. Pages 105-113 in C. C. Coutant, editor. Behavioral Technologies for Fish Guidance. Amer Fisheries Soc, Bethesda.

Davey, A. J. H. and D. J. Jellyman. 2005. Sex determination in freshwater eels and management options for manipulation of sex. Reviews in Fish Biology and Fisheries 15:37-52.

DeLeo, G. A. and M. Gatto. 1996. Trends in vital rates of the European eel: Evidence for density dependence? Ecological Applications 6:1281-1294.

Ducheney, P., R.F. Murray, J.E. Waldrip, and C. A. Tomichek. 2006. Fish Passage at Hadley Falls: Past, Present, and Future. Page 15 in Hydrovision 2006 Proceedings. HCI Publications.

Durif, C. M. F., P. Elie, C. Gossett, J. Rives, and F. Travade. 2003. Behavioral study of downstream migrating eels by radio-telemetry at a small hydroelectric power plant. Pages 343-356 in D. A. Dixon, editor. Biology, Management, and Protection of Catadromous Eels. American Fisheries Society, Bethesda.

EPRI (Electric Power Research Institute). 2001. Evaluation of Angled Bar Racks and Louvers for Guiding Fish at Water Intakes. EPRI (Palo Alto, CA) and Dominion Millstone Laboratories (Waterford, CT).

Facey, D. E. and M. J. V. D. Avyle. 1987. Species profiles : life histories and environmental requirements of coastal fishes and invertebrates (North Atlantic) - American eel. U.S. Fish Wildlife Service and U.S. Army Corps of Engineers.

Fenske, K. H. 2009. Assessment of local abundance, demographics, health and exploitation of Chesapeake Bay American eel. University of Maryland, College Park, MD.

Friedland, K. D., M. J. Miller, and B. Knights. 2007. Oceanic changes in the Sargasso Sea and declines in recruitment of the European eel. Ices Journal of Marine Science 64:519-530.

Geer, P. J. 2003. Distribution, relative abundance, and habitat use of American eel Anguilla rostrata in the Virginia portion of the Chesapeake Bay. Pages 101-115 in D. A. Dixon, editor. Biology, Management, and Protection of Catadromous Eels. Amer Fisheries Soc, Bethesda.

Goodwin, K. R. and P. L. Angermeier. 2003. Demographic characteristics of American eel in the Potomac River drainage, Virginia. Transactions of the American Fisheries Society 132:524-535.

Gosset, C., F. Travade, C. Durif, J. Rives, and P. Elie. 2005. Tests of two types of bypass for downstream migration of eels at a small hydroelectric power plant. River Research and Applications 21:10951105.

Gunning, G. E. and C. R. Shoop. 1962. Restricted movements of the American eel, Anguilla rostrata (LeSueur), in freshwater streams, with comments on growth rate. Tulane Studies in Zoology 9:265-272.

Hadderingh, R. H. and H. D. Bakker. 1998. Fish mortality due to passage through hydroelectric power stations on the Meuse and Vecht rivers. Pages 315-328 Fish Migration and Fish Bypasses.

Hadjerioua, B., S.-C. Kao, M. J. Sale, Y. Wei, S. K. SanthanaVannan, H. A. Shanafield III, D. P. Kaiser, R. Devarakonda, C. Odeh, G. Palanisamy, and B. T. Smith. 2011. National Hydropower Asset Assessment Project. U.S. Department of Energy, Oak Ridge National Laboratory.

Haro, A. J. 1991. Thermal preferenda and behavior of atlantic eels (Genus Anguilla) in relation to their spawning migration. Environmental Biology of Fishes 31:171-184.

Haro, A. J., T. Castro-Santos, and J. Boubee. 2000a. Behavior and passage of silver-phase American eels, Anguilla rostrata (LeSueur), at a small hydroelectric facility. Dana-a Journal of Fisheries and Marine Research 12:33-42. 
Haro, A. J., T. Castro-Santos, K. Whalen, G. Wippelhauser, and L. McLaughlin, editors. 2003. Simulated effects of hydroelectric project regulation on mortality of American eels. Amer Fisheries Soc, Bethesda.

Haro, A. J., W. Richkus, K. Whalen, A. Hoar, W. D. Busch, S. Lary, T. Brush, and D. Dixon. 2000b. Population decline of the American eel: Implications for research and management. Fisheries 25:7-16.

Hightower, J. E. and C. Nesnow. 2006. Distribution and abundance of American eels in the White Oak River estuary, North Carolina. Southeastern Naturalist 5:693-710.

Hitt, N. P., S. Eyler, and J. E. B. Wofford. 2012. Dam Removal Increases American Eel Abundance in Distant Headwater Streams. Transactions of the American Fisheries Society 141:1171-1179.

Jager, H. I., R. A. Efroymson, J. A. Opperman, and M. R. Kelly. in review. Sustainable river basin design: Using spatial decisions to manage river portfolios. Bioscience.

Jansen, H. M., H. V. Winter, M. C. M. Bruijs, and H. J. G. Polman. 2007. Just go with the flow? Route selection and mortality during downstream migration of silver eels in relation to river discharge. ICES Journal of Marine Science: Journal du Conseil 64:1437-1443.

Jessop, B. M. 2000. Estimates of population size and instream mortality rate of American eel elvers in a Nova Scotia river. Transactions of the American Fisheries Society 129:514-526.

Kleckner, R. C., J. D. McCleave, and G. S. Wippelhauser. 1983. Spawning of American eel, Anguilla rostrata, relative to thermal fronts in the Sargasso Sea. Environmental Biology of Fishes 9:289293.

Kocovsky, P. M., R. M. Ross, and D. S. Dropkin. 2008. Linking landscapes and habitat suitability scores for diadromous fish restoration in the Susquehanna River basin. North American Journal of Fisheries Management 28:906-918.

Laffaille, P., A. Acou, J. GuillouËT, and A. Legault. 2005. Temporal changes in European eel, Anguilla anguilla, stocks in a small catchment after installation of fish passes. Fisheries Management and Ecology 12:123-129.

Lamson, H. M., D. K. Cairns, J. C. Shiao, Y. Iizuka, and W. N. Tzeng. 2009. American eel, Anguilla rostrata, growth in fresh and salt water: implications for conservation and aquaculture. Fisheries Management and Ecology 16:306-314.

Larinier, M. and F. Travade. 2002. Downstream migration: Problems and facilities. Bull. Fr. Pêche Piscic.:181-207.

MacGregor, R., J. M. Casselman, W. A. Allen, T. Haxton, J. M. Dettmers, A. Mathers, S. LaPan, T. C. Pratt, P. Thompson, M. Stanfield, L. Marcogliese, and J. D. Dutil. 2009. Natural Heritage, Anthropogenic Impacts, and Biopolitical Issues Related to the Status and Sustainable Management of American Eel: A Retrospective Analysis and Management Perspective at the Population Level. Pages 713-740 in A. Haro, K. L. Smith, R. A. Rulifson, C. M. Moffitt, R. J. Klauda, M. J. Dadswell, R. A. Cunjak, J. E. Cooper, K. L. Beal, and T. S. Avery, editors. Challenges for Diadromous Fishes in a Dynamic Global Environment. Amer Fisheries Soc, Bethesda.

Machut, L. S., K. E. Limburg, R. E. Schmidt, and D. Dit-Rman. 2007. Anthropogenic impacts on American eel demographics in Hudson River tributaries, New York. Transactions of the American Fisheries Society 136:1699-1713.

McCleave, J. D. 1993. Physical and behavioral controls on the oceanic distribution and migration of leptocephali. Journal of Fish Biology 43:243-273.

McCleave, J. D. and R. C. Kleckner. 1982. Selective tidal stream transport in the estuarine migration of glass eels of the American eel (Anguilla rostrata) Journal Du Conseil 40:262-271.

McGrath, K. J., J. W. Dembeck, J. B. McLaren, A. A. Fairbanks, K. Reid, and S. J. Cluett, editors. $2003 a$. Surface and midwater trawling for American eels in the St. Lawrence River. Amer Fisheries Soc, Bethesda.

McGrath, K. J., D. Desrochers, C. Fleury, and J. W. Dembeck. 2003b. Studies of upstream migrant American eels at the Moses-Saunders power dam on the St. Lawrence River near Massena, New 
York. Pages 153-166 in D. A. Dixon, editor. Biology, Management, and Protection of Catadromous Eels. Amer Fisheries Soc, Bethesda.

McGrath, K. J., R. Verdon, D. Desrochers., C. Fleury, S. Ault, and J. Skalski. 2009. Determining exit locations for eel ladders at hydroelectric power dams on the St. Lawrence River. Pages 293-308 in J. M. Casselman and D. K. Cairns, editors. Eels at the edge. American Fisheries Society, Bethesda, MD.

Morrison, W. E. and D. H. Secor. 2003. Demographic attributes of yellow-phase American eels (Anguilla rostrata) in the Hudson River estuary. Canadian Journal of Fisheries and Aquatic Sciences 60:1487-1501.

Morrison, W. E., D. H. Secor, and P. M. Piccoli. 2002. Estuarine habitat use by Hudson river American eels as determined by otolith Strontium : Calcium ratios. Pages 87-99 in D. A. Dixon, editor. Biology, Management, and Protection of Catadromous Eels. Amer Fisheries Soc, Bethesda.

Mueller, A. M., T. Mulligan, and P. K. Withler. 2008. Classifying Sonar Images: Can a Computer-Driven Process Identify Eels? North American Journal of Fisheries Management 28:1876-1886.

NatureServe. 2004. Downloadable Animal Datasets. NatureServe.

Nilsson, C., C. A. Reidy, M. Dynesius, and C. Revenga. 2005. Fragmentation and flow regulation of the world's large river systems. Science 308:405-408.

Oliveira, K. and J. D. McCleave. 2000. Variation in population and life history traits of the American eel, Anguilla rostrata, in four rivers in Maine. Environmental Biology of Fishes 59:141-151.

Oliveira, K. and J. D. McCleave. 2002. Sexually different growth histories of the American eel in four rivers in Maine. Transactions of the American Fisheries Society 131:203-211.

Oliveira, K., J. D. McCleave, and G. S. Wippelhauser. 2001. Regional variation and the effect of lake: river area on sex distribution of American eels. Journal of Fish Biology 58:943-952.

Overton, A. and R. Rulifson. 2009. Annual variability in upstream migration of glass eels in a southern USA coastal watershed. Environmental Biology of Fishes 84:29-37.

Parker, S. J. and J. D. McCleave. 1997. Selective tidal stream transport by American eels during homing movements and estuarine migration. Journal of the Marine Biological Association of the United Kingdom 77:871-889.

Patrick, P. H., J. S. Poulton, and R. Brown. 2001. Responses of American eels to strobe light and sound (preliminary data) and introduction to sound conditioning as a potential fish passage technology. Pages 1-11 in C. C. Coutant, editor. Behavioral Technologies for Fish Guidance. Amer Fisheries Soc, Bethesda.

Pelicice, F. M. and A. A. Agostinho. 2008. Fish-passage facilities as ecological traps in large neotropical rivers. Conservation Biology 22:180-188.

Porcher, J. P. 2002. Fishways for eels. Bull. Fr. Pêche Piscic.:147-155.

Pujolar, J. M. 2013. Conclusive evidence for panmixia in the American eel. Molecular Ecology 22:17611762.

Richkus, W. A. 2001. Review and documentation of research and technologies and passage on downstream migrating catadromous eels at hydroelectric facilities. Electric Power Research Institute.

Richkus, W. A. and D. A. Dixon. 2003. Review of research and technologies on passage and protection of downstream migrating catadromous eels at hydroelectric facilities. Pages 377-388 in D. A. Dixon, editor. Biology, Management, and Protection of Catadromous Eels.

Richkus, W. A. and K. Whalen. 1999. American Eel (Anguilla rostrata) Scoping Study: A literature and data review of life history, stock status, population dynamics, and hydroelectric impacts., Electric Power Research Institute, Palo Alto, CA.

Richkus, W. A. and K. Whalen. 2000. Evidence for a decline in the abundance of the American eel, Anguilla rostrata (LeSueur), in North America since the early 1980's. Dana-a Journal of Fisheries and Marine Research 12:83-97.

Sand, O., P.S. Enger, H.E. Karlsen, and F. R. Knutsen. 2001. Detection of infrasound in fish and behavioral responses to intense infrasound in juvenile salmonids and European silver eels: A 
minireview. Pages 183-193 in C. C. Coutant, editor. Behavioral Technologies for Fish Guidance. American Fisheries Society, Bethesda, MD.

Schmidt, R. E., C. M. O'Reilly, and D. Miller. 2009. Observations of American Eels Using an Upland Passage Facility and Effects of Passage on the Population Structure. North American Journal of Fisheries Management 29:715-720.

Smogor, R. A., P. L. Angermeier, and C. K. Gaylord. 1995. Distribution and abundance of American eels in Virginia stream -- tests of null models across spatial scales. Transactions of the American Fisheries Society 124:789-803.

Sorensen, P. W. and M. L. Bianchini. 1986. Environmental correlates of the freshwater migration of elvers of the American eel in a Rhode Island brook. Transactions of the American Fisheries Society 115:258-268.

Stuart, I. G., J. D. Koehn, T. A. O'Brien, J. A. McKenzie, and G. P. Quinn. 2010. Too close for comfort: a fishway exit and a hydro-power station inlet. Marine and Freshwater Research 61:23-33.

Sullivan, M. C., K. W. Able, J. A. Hare, and H. J. Walsh. 2006. Anguilla rostrata glass eel ingress into two, US east coast estuaries: patterns, processes and implications for adult abundance. Journal of Fish Biology 69:1081-1101.

Thibault, I., J. J. Dodson, and F. Caron. 2007a. Yellow-stage American eel movements determined by microtagging and acoustic telemetry in the St Jean River watershed, Gaspe, Quebec, Canada. Journal of Fish Biology 71:1095-1112.

Thibault, I., J. J. Dodson, F. Caron, W. N. Tzeng, Y. Iizuka, and J. C. Shiao. 2007b. Facultative catadromy in American eels: testing the conditional strategy hypothesis. Marine Ecology Progress Series 344:219-229.

US Fish and Wildlife Service. 2011. Endangered and Threatened Wildlife and Plants; 90-Day Finding on a Petition To List the American Eel as Threatened. 50 CFR Part 17, Federal Register.

Verdon, R. 2003. Upstream migratory movements of American eel Anguilla rostrata between the Beauharnois and Moses-Saunders power dams on the St. Lawrence River. Pages 139-151 in D. A. Dixon, editor. Biology, Management, and Protection of Catadromous Eels. Amer Fisheries Soc, Bethesda.

Verdon, R., D. Desrochers, and P. Dumont. 2003. Recruitment of American eels in the Richelieu River and Lake Champlain: Provision of upstream passage as a regional-scale solution to a large-scale problem. Pages 125-138 in D. A. Dixon, editor. Biology, Management, and Protection of Catadromous Eels. Amer Fisheries Soc, Bethesda.

Verreault, G. and P. Dumont. 2003. An estimation of American eel escapement from the upper St. Lawrence River and Lake Ontario in 1996 and 1997. Pages 243-251 in D. A. Dixon, editor. Biology, Management, and Protection of Catadromous Eels. Amer Fisheries Soc, Bethesda.

Versar, I. 2009. Review of Technologies for Guiding, Capturing, Holding, Transporting, and Monitoring Outmigrating Eels. New York Power Authority, 9200 Rumsey Road, Columbia, MD 21045.

Walsh, P. J., G. D. Foster, and T. W. Moon. 1983. The effects of temperature on metabolism of the American eel Anguilla-rostrata (LeSeuer) - Compensation in the summer and torpor in the winter. Physiological Zoology 56:532-540.

Watene, E. M. and J. A. T. Boubee. 2005. Selective opening of hydroelectric dam spillway gates for downstream migrant eels in New Zealand. Fisheries Management and Ecology 12:69-75.

Watene, E. M., J. A. T. Boubee, and A. Haro. 2003. Downstream movement of mature eels in a hydroelectric reservoir in New Zealand. Pages 295-305 in D. A. Dixon, editor. Biology, Management, and Protection of Catadromous Eels. American Fisheries Society, Bethesda.

Wenner, C. A. and J. A. Musick. 1974. Fecundity and gonad observations of American eel, Anguilla rostrata, migrating from Chesapeake Bay, Virginia. Journal of the Fisheries Research Board of Canada 31:1387-\&.

Wiley, D. J., R. P. Morgan, R. H. Hilderbrand, R. L. Raesly, and D. L. Shumway. 2004. Relations between physical habitat and American eel abundance in five river basins in Maryland. Transactions of the American Fisheries Society 133:515-526. 
Winter, H. V., H. M. Jansen, and A. Breukelaar. 2007. Silver eel mortality during downstream migration in the River Meuse, from a population perspective. Ices Journal of Marine Science 64:1444-1449. Yerger, R. W. 1977. Fishes of the Apalachicola River. Florida Marine Research Publications 26:22-33. 


\section{APPENDIX A. PROTECTION UNDER THE ENDANGERED SPECIES ACT}

This appendix summarizes the proposed ESA listing and reviews the literature to address three key questions that inform the listing process: (1) Is the eel population declining? (2) What are the potential causes of declines? (3) How has hydropower contributed to the decline? Considerations are listed in Table 2.

In 2011, the US Fish and Wildlife Service (USFWS) announced a 90-day finding on a petition to list the American eel (Anquilla rostrata). Studies have found statistically significant declines in eel catch per unit of effort in Ontario, Quebec, New York, and Virginia and no increases in any rivers between 1984 and 1995 (Richkus and Whalen 2000). Haro et al. (2000b) detected decreasing trends in yellow eels but stable catches of glass eels between 1984 and 1995. Going back farther in history, early settler accounts remind us of the huge abundances of eels in the St Lawrence River (MacGregor et al. 2009), followed by declines (Verreault and Dumont 2003). Despite these concerns, the USFWS examined the evidence and determined that there is no range-wide decline in elvers and glass eels or in marine harvest. Furthermore, the finding indicated that eels remain viable in large numbers over a wide geographic range. However, the USFWS acknowledged declines in yellow eels and considers these a good index of range-wide abundance.

The finding examined new evidence brought forward since the 2007 decision. New evidence for threats from hydropower and contaminants was not sufficient to warrant further investigation. However, new evidence for an increase in ocean temperatures in the Sargasso Sea-leading to a recent shift in spawning location, reduced food availability for leptocephali (Bonhommeau et al. 2008), and shifts in ocean currents transporting leptocephali-was considered substantial enough to find that it may pose a significant threat to the American eel. Recent evidence for a similar impact on the ocean survival of the European eel by (Friedland et al. 2007) contributed to the finding, because the European eel breeds in the same area. Thus the threat of significant disruption of the life cycle caused by climate change effects is the primary basis for continued review.

Unlike salmon and sturgeon, the American eel will likely be managed as a single genetic stock. This is because American eel exist as one panmictic population breeding in the Sargasso Sea (Pujolar 2013). After spawning in the Sargasso Sea, juvenile elvers ride the Gulf Stream to coastal estuaries of the Atlantic coast in the United States and Canada, with a much smaller fraction entering the Florida Gulf stream. Some juveniles swim upstream into rivers and others remain in the estuary. Those traveling farthest upstream tend to grow the slowest and become females. These large females are important because they must travel downriver to return to the Sargasso Sea to reproduce.

The implications of panmixia for conservation are

- The species does not enjoy the benefits of a metapopulation structure. In a metapopulation, when one population is extirpated, it may be rescued by immigrants from other, nearby populations. Disruption of transport could potentially wipe out the whole population if currents do not return rearing eels to the same place.

- Adaptation to local conditions in streams and rivers is not genetically possible.

- Incentives for recovery are weaker than for homing species because juvenile eels do not necessarily return to the river that their parents inhabited. In other words, river basin restoration groups and utilities may not reap the benefits of mitigation actions, potentially leading to a "tragedy of the commons.” 


\section{Table A1. Factors used to make a listing determination under the Endangered Species Act}

- The present or threatened destruction, modification, or curtailment of its habitat or range.

- Overutilization for commercial, recreational, scientific, or educational purposes.

- $\quad$ Disease or predation, specifically the prevalence of the parasite Anguillicola crassus in the American eel.

- $\quad$ The inadequacy of existing regulatory mechanisms.

- Data that support either the existence of a population structure to the degree that a threat could have differentiating effects on portions of the population and not on the whole species, or the claim that eels are panmictic (having one, well-mixed breeding population). These data may show evidence for genetic differences that result in selective growth, sex ratios, increased vulnerability to threats, or habitat preferences.

- Information demonstrating or refuting statistically significant long-term glass eel recruitment declines.

- Information on the correlation between climate change and glass eel recruitment, such as Atlantic oceanic conditions data, analyses, and predictions including, but not limited to

o Climate change predictions over the next 25, 50, 75, and/or 100 years as they relate to ocean circulation, changes in the Sargasso sea circulation, sea surface temperature (SST), or larvae and glass eel food availability, either directly or indirectly through changes in SST that affect primary productivity

o Quantitative research on the food of eel larvae and the relationship of food availability to survival of eel larvae

o Further investigations into the indirect effects of a change in SST on nutrient circulation due to enhanced stratification of the water column and its effects on phytoplankton communities

o The length of time eel larvae take to migrate to the Atlantic coast from the Sargasso Sea

o The impact of food availability along the entire migration route on eel larvae survival

o Threats to the Sargasso Sea of the magnitude that would be predicted to affect glass eel recruitment, and information on increased larval retention in the Sargasso Sea gyre resulting from changes in winds due to climate change 